\title{
Quantifying macrodetritus fluxes from a small temperate estuary
}

Rebecca V. Gladstone-Gallagher*1, Dean R. Sandwell ${ }^{1}$, Andrew M. Lohrer ${ }^{2}$, Carolyn J. Lundquist $^{2,3}$, Conrad A. Pilditch ${ }^{1}$

${ }^{1}$ School of Science, University of Waikato, Hamilton 3240, New Zealand

${ }^{2}$ National Institute of Water and Atmospheric Research Ltd. (NIWA), Hamilton 3216, New Zealand

${ }^{3}$ Institute of Marine Science, University of Auckland, Auckland 1142, New Zealand

* Corresponding author email: rgladstonegallagher@gmail.com 


\section{Table of contents abstract}

2 Hydrodynamics drive the export of estuarine-derived primary production and nutrients to

3 adjacent less productive offshore waters. This study quantified estuary-to-coast fluxes of

4 detritus and nutrients by sampling the water at the mouth of a small temperate estuary.

5 These types of studies are important to determine the ecosystem services provided by

6 temperate estuaries.

\section{Abstract}

8 Empirical measurements of estuary-to-coast material fluxes usually exclude the fraction of

9 primary production that is exported as macrodetritus (marine plant litter), potentially

10 leaving a gap in our understanding of the role of estuaries as outwelling systems. To

11 address this gap, we sampled water and suspended material seasonally from the mouth of

12 Pepe Inlet, Tairua Estuary, New Zealand. From samples collected hourly over 24 h, we

13 calculated the lateral tidal fluxes (import, export, net flux) of macrodetritus,particulate and

14 dissolved forms of nitrogen $(\mathrm{N})$ and phosphorus $(\mathrm{P})$. Annually, the inlet was a net exporter

15 of $\mathrm{N}$ and $\mathrm{P}(5145 \mathrm{~kg} \mathrm{~N}$ and $362 \mathrm{~kg} \mathrm{P})$. However, macrodetritus accounted for $<13 \%$ and

$16<3 \%$ of seasonal $\mathrm{N}$ and $\mathrm{P}$ exports, respectively. Macrodetritus is an obvious and visible

17 source of estuary-to-coast subsidy, but our derived nutrient budgets suggest the dissolved

18 and particulate forms dominate the net export of $\mathrm{N}$ and $\mathrm{P}(>87 \%)$. Nevertheless, seasonal

19 pulses in the source and supply of macrodetritus may have consequences for the temporal

20 scales over which this resource subsidy affects receiving ecosystems (e.g. intertidal

21 sandflats). These mensurative investigations are useful to inform estuarine nutrient budgets

22 that quantify the ecosystem services provided by temperate estuaries (e.g. contribution to

23 fisheries foodwebs). 
24 Additional keywords: Estuarine flux; Outwelling hypothesis; Detritus; Spatial subsidies;

25 Macrophyte detritus

26 Running title: Macrodetritus fluxes from a small temperate estuary 


\section{Introduction}

28 Temperate estuaries/lagoons are considered among the Earth's most productive marine

29 ecosystems, containing diverse vegetated (e.g. mangroves, saltmarsh, seagrass) and

30 unvegetated habitats (e.g. intertidal sand and mud flats) (Eyre and Balls 1999; Underwood

31 and Kromkamp 1999; Odum 2000; Valiela et al. 2000). Microphytobenthos in unvegetated

32 sediments alone can contribute $\sim 50 \%$ of the total estuarine primary production

33 (Underwood and Kromkamp 1999), and marine vegetated habitats constitute hotspots of

34 productivity, producing substantial amounts of leaf litter detritus (e.g. temperate mangroves up to $12.5 \mathrm{t} \mathrm{DW} \mathrm{ha}^{-1}$ year $^{-1}$; reviewed in Morissey et al. 2010). Many estuaries tidally exchange large proportions of their water volume with the coastal ocean.

37 Consequently, these hydrodynamics drive the export of estuarine production to adjacent less productive offshore waters (up to 100's kilometres offshore; i.e. the 'outwelling hypothesis' of Odum 1968; Dame and Allen 1996; Odum 2000). Through outwelling,

40 estuaries contribute to the coastal oceanic food web (Doi et al. 2009; Savage et al. 2012)

41 and ecosystem services that society values (e.g. fisheries; Barbier et al. 2011; Savage et al. 42 2012).

43 Since the formulation of the 'outwelling hypothesis' (Odum 1968), numerous studies have attempted to test and expand on it (reviewed in Nixon 1980; Odum 2000; Childers et al. 2000; Valiela et al. 2000). Naturally occurring stable isotopes (e.g. Doi et al. 2009; Granek et al. 2009; Savage et al. 2012) and sediment lignin content analyses (reviewed in Valiela et al. 2000) have confirmed that estuarine primary production is transported (often at a scale of kilometres) and incorporated into adjacent coastal food webs. However, these studies reveal little of the magnitude of the subsidy, that is, the amount of organic matter 
exported from estuarine habitats, as well as the proportion of production that is exported vs. retained and recycled within the estuarine system (i.e. net fluxes).

Direct quantification of estuary-to-coast subsidies to date have mostly focused on fluxes of suspended fine particles and solutes (i.e. particulate and dissolved matter), usually involving temporal water sampling in a tidal creek/channel (e.g. Borey et al. 1983; Dankers et al. 1984; Baird et al. 1987; Boto and Wellington 1988; reviewed in Valiela et al. 2000; Sánchez-Carillo et al. 2009). However, very few studies have directly measured estuary-to-coast fluxes of macrodetritus (large pieces of plant litter, including leaf, wood, and propagule material), due to the associated logistical challenges. Consequently, macrodetritus fluxes are often excluded from estuarine nutrient/production budgets (e.g.

60 Valiela et al. 2000), or instead estimated based on in situ production, decay, and

61 consumption rates within the ecosystem (e.g. from a mangrove forest: Boto and Bunt 1981; Robertson 1986; from a seagrass bed: Pergent et al. 1997). Since marine plants produce large quantities of leaf litter, estimates of macrodetritus export can be quite large (e.g. in a mangrove-dominated inlet, macrodetritus export of $15.3-19.5 \mathrm{~kg} \mathrm{DW} \mathrm{ha}^{-1} \mathrm{day}^{-1}$ is estimated to be $6 \times$ greater than particulate transport; Boto and Bunt 1981; Robertson 1986). Therefore, the exclusion of the macrodetritus fluxes leaves a potentially large gap in our understanding of the contributions of estuarine production to adjacent coastal environments.

The form in which production is exported (i.e. dissolved nutrients, particulate, or macrodetritus) will have consequences for its utilisation by the receiving environment, and

71 influence how quickly this production is incorporated into coastal food webs. Particulate

72 organic carbon $(\mathrm{C})$, nitrogen $(\mathrm{N})$, and phosphorus $(\mathrm{P})$ (which broadly includes organic matter associated with suspended sediment, phytoplankton, and decayed fragmented 
detritus) are forms that are available to be immediately consumed by macrofaunal consumers, while bacteria, microphytes, and macrophytes can utilise the dissolved inorganic forms. However, because macrodetrital decay is relatively slow (reviewed in Enriquez et al. 1993), the temporal scales over which macrodetritus is utilised may be greater than that of particulates and dissolved nutrients, giving it the opportunity to also be transported over greater spatial scales. Accordingly, the main role of this form of production may instead be in structuring macroinvertebrate communities in receiving environments (e.g. Kelaher and Levinton 2003; Bishop and Kelaher 2007), or acting as a primary production source to marine environments with low in situ production (e.g. deep subtidal marine environments below the photic zone; Britton-Simmons et al. 2009).

Of the studies that have directly quantified net macrodetrital export from estuaries, most have been limited to saltmarsh-dominated lagoon systems in the northern hemisphere (Dame 1982; Dame and Stillwell 1984; Hemminga et al. 1996; Bouchard and Lefeuvre 2000), and/or focused on macrodetrital fluxes from just one vegetation type (e.g. macroalgae, Biber 2007; mangrove litter, Woodroffe 1985; Wattayakorn et al. 1990; Silva et al. 1993 as cited in Ramos e Silva et al. 2007 p. 528; Rajkaren and Adams 2007; see summary of macrodetritus flux studies in Table A1 in Appendices). In addition, many of these studies have been conducted in estuarine/lagoon systems that are atypical of temperate mixed habitat estuaries. For example, Tuff Crater (New Zealand) is a mangrovedominated, enclosed crater that exchanges tidal water through a single break in the crater wall (Woodroffe 1985); Mont Saint-Michel Bay (France) is a macro-tidal bay with a very large average tidal range of 12 m (Bouchard and Lefeuvre 2000); whilst Biscayne Bay (Florida, USA) is a large, open coastal cut separated by coastal islands (Biber 2007; Table

97 A1). Thus, generalisation of the fluxes measured in these study systems to other temperate estuaries is difficult. Dame and colleagues (Dame 1982; Dame and Stilwell 1984; Dame et 
al. 1986) constructed export budgets after sampling all of the production size fractions in a

100 South Carolina tidal marsh system (North Inlet), and suggested that macrodetritus

101 constituted a relatively small proportion of the total outwelled production. We took a

102 similar approach here to evaluate estuary-to-coast subsidies in a well-defined part of a

103 small New Zealand estuary.

104 As the supply and quality of estuarine subsidies are temporally variable (reviewed in

105 Odum 2000), it is important that estuary-to-coast flux studies effectively encompass

106 seasonal variability. In temperate climates, marine plant productivity is highly seasonal,

107 with temporal pulses in the supply of leaf litter associated with seasonal production peaks

108 (usually in summer or spring; e.g. Turner 2007; Imgraben and Dittmann 2008; Gladstone-

109 Gallagher et al. 2014). Temporal variation in the supply of terrestrially derived detritus and

110 nutrients is likely to be associated with spring-neap tidal cycles (i.e. spring tides will

111 potentially inundate more terrestrial habitat to mobilise detritus), and seasonal rainfall

112 levels (that can wash terrestrial detritus into the marine system). Further, shallow-water

113 unvegetated benthic habitats rely on light reaching the sediment surface for production

114 (Lohrer et al. 2015; Needham et al. 2011), and therefore the associated uptake of nutrients

115 (before they can be exported out of the estuary) by the benthos may be tightly coupled

116 with seasonal day length and weather conditions.

117 Quarterly, at the mouth of a tidally-dominated temperate sub-estuary, we measured the

118 flux of macrodetritus, dissolved and particulate forms of $\mathrm{N}$ and $\mathrm{P}$, as well as chlorophyll $a$

119 (chl $a$ ) to increase understanding of the seasonal variability in the source and quantity of

120 production that is transported across the boundary of a small temperate estuary. The study

121 was designed to: 1) obtain empirical data on the magnitude of macrodetrital fluxes from a

122 mixed habitat estuary that is typical of estuaries in the North Island of New Zealand (i.e. 
123 large intertidal areas, with large tidal water exchange); and 2) increase our knowledge of

124 the magnitude of export of production in a tidal estuary, with particular emphasis on the

125 contribution of macrodetritus to the total exported production, N and P. Studies such as

126 this contribute to understanding of how anthropogenic habitat degradation (e.g. mangrove

127 forest clearances and seagrass bed declines that can change the supply of detritus available

128 to be exported; Inglis 2003; Moore and Short 2006; Orth et al. 2006; Harty 2009) may

129 affect the ecosystem services associated with production outwelling from temperate

130 estuaries.

\section{$131 \quad$ Materials and methods}

\section{Site description}

133 Tairua Estuary $\left(37^{\circ} 00^{\prime} 05^{\prime} \mathrm{S}, 175^{\circ} 50^{\prime} 42^{\prime}\right.$ E) is located on the east coast of the Coromandel

134 Peninsula (Fig. 1), and is representative of a common type of estuary in the North Island of

135 New Zealand (Hume et al. 2007). Tairua Estuary is a 605 ha barrier-enclosed lagoon, of

136 which $71 \%$ (of the high tide area) is intertidal (Fig. 1), and the mean water depth at mid-

137 tide is $\sim 2 \mathrm{~m}$ (Hume and Herdendorf 1993; Bell 1994). The estuary is well flushed, taking

1381.3 tidal cycles to flush the entire tidal prism, and $82 \%$ of the water that enters the estuary

139 during each flooding tide is 'new' ocean water (Bell 1994). The estuary has spring and

140 neap tidal ranges of $1.63 \mathrm{~m}$ and $1.22 \mathrm{~m}$, respectively (Liu 2014). The estuary's 29,381 ha

141 catchment is occupied by a number of land uses, including forestry, pasture, and small

142 urban settlements, as well as indigenous forest and scrub (O’Donnell 2011).

143 Pepe Inlet is a 26 ha tidally-dominated inlet within Tairua Estuary (Fig. 1). The inlet

144 tidally drains through a single mouth ( $\sim 37 \mathrm{~m}$ wide), and has one main freshwater input at

145 Pepe Stream, which discharges on average $0.23 \mathrm{~m}^{3} \mathrm{~s}^{-1}$ of water into the estuary (mean 
146 annual discharge; Liu 2014). Pepe Inlet supports diverse marine vegetated habitats, which

147 include mangrove forest (Avicennia marina subsp. australasica; $\sim 3$ ha, $\sim 11 \%$ of estuary

148 area), seagrass beds (Zostera muelleri; $\sim 2$ ha, $\sim 8 \%$ of estuary area), and saltmarsh ( 10 ha;

149 made up of various rushland, saltwater paspallum, Spartina spp., salt meadow, and

150 saltmarsh ribbonwood species, some of which is above mean high water springs; Fig. 1;

151 Graeme 2008; Felsing and Giles 2011). Macroalgae (Hormosira banksii) also grow within 152 and outside the mouth of the inlet (Graeme 2008). The unvegetated sediments within Pepe

153 Inlet are comprised mainly of fine to medium sands (Felsing and Giles 2011). Sampling

154 was done at the mouth of Pepe Inlet, and at Pepe Stream (Fig. 1C) to determine the flux of

155 macrodetritus, dissolved and particulate nutrients from this sub-estuary to the wider

156 estuary/coastal system. The well constrained mouth, as well as the mixture of vegetation

157 types within Pepe Inlet make this estuary an ideal place to study material fluxes.

158 During the study period (May 2014-February 2015), the Coromandel region had maximum

159 and minimum daily air temperatures of $28.9^{\circ} \mathrm{C}$ and $-1.8^{\circ} \mathrm{C}$, respectively. Total rainfall over

$160 \mathrm{a} 48 \mathrm{~h}$ period ( $24 \mathrm{~h}$ before, and during each sampling period) was $0.4,0.2,12.8$, and 6.8

$161 \mathrm{~mm}$, in May, July, November, and February, respectively (climate data obtained from the

162 NIWA CliFlo database at http://cliflo.niwa.co.nz; data from the Whitianga weather station, $163 \sim 30 \mathrm{~km}$ from Tairua).

164 Sampling regime

165 To derive material fluxes, we sampled macrodetritus, water column chl $a$ (an indicator of 166 phytoplankton and resuspended benthic microphyte biomass), total dissolved $\mathrm{N}$ and $\mathrm{P}$

167 (TDN and TDP; includes both inorganic and organic components), as well as total

168 particulate $\mathrm{N}$ and $\mathrm{P}$ (TPN and TPP) concentrations, over a $24 \mathrm{~h}$ period (two ebb and two

169 flood tides). The $24 \mathrm{~h}$ sampling was repeated in May (late-autumn = Aut), July (mid- 
170 winter $=$ Win $)$, November (late-spring $=$ Spr $)$, and February (late-summer $=$ Sum $) .24 \mathrm{~h}$

171 sampling periods were chosen during spring tides, and sampling encompassed both

172 midday and midnight high tides to reduce the variability between sampling dates that may

173 be confounded by diurnal uptake of inorganic nutrients (i.e. by microalgae during

174 photosynthesis; Lohrer et al. 2015).

175 Suspended macrodetritus was sampled using nets positioned in the mouth of Pepe Inlet,

176 which were emptied on each slack tide (as the tidal flow direction changed). Three nets

177 (opening: $50 \times 100 \mathrm{~cm}$, length: $100 \mathrm{~cm}$, mesh size: $4 \times 4 \mathrm{~mm}$ ) were placed at two positions

178 within the $37 \mathrm{~m}$ wide channel (6 nets total; sampling $5.4 \%$ of the channel width), with

179 three nets stacked on top of one another (Fig. A1 in Appendices). The bottom and middle

180 nets were kept at a fixed depth, while the top net floated and sunk as the tide rose and fell

181 to sample the surface waters. All nets were attached to a central pole, enabling them to

182 change direction with the water flow.

183 Preliminary depth profiles (as well as hourly depth profiles during all sampling dates; 0.1

$184 \mathrm{~m}$ depth intervals) of salinity, temperature, and dissolved oxygen (DO; Multi-parameter

185 water quality Sonde 600QS; YSI Inc.) indicated that Pepe Inlet channel remained well

186 mixed for most of the tidal cycle (and during times of greatest tidal exchange; see results).

187 Because the channel remained well-mixed, water samples (1 L) were collected half hourly

188 in the centre of the channel using a Van Dorn water sampler (3.2 L, PVC, ENVCO)

189 lowered just below the water surface. To sample the freshwater input into the estuary, a

190 portable vacuum sampler (model: VST, Manning Environmental Inc.) was positioned to

191 collect surface water (0.5 L) in the centre of Pepe Stream half hourly into acid washed

192 containers. 
193 One $100 \mathrm{ml}$ water sample from each half hourly sampling was immediately pressure

194 filtered through two $25 \mathrm{~mm}$ Whatman GF/C fibreglass filters, and the filtrate and filters

195 were frozen for later analysis of dissolved nutrients and chl $a$, respectively. The remaining

196 water from each half hour sample was then pooled across $2 \mathrm{~h}$ for measurement of

197 particulate $\mathrm{N}$ and $\mathrm{P}$ (i.e. TPN and TPP), and filtered through pre-weighed $45 \mathrm{~mm}$ Whatman

198 GF/C fiberglass filters using a vacuum pump (i.e. particulates include suspended particles,

199 from $0.5-1.75 \mathrm{~L}$ water samples, retained on $1.2 \mu \mathrm{m}$ pore size fiberglass filter; the sample

200 volume depended on the amount suspended content). Filters for TPN and TPP were also

201 frozen awaiting analysis.

202 During each $24 \mathrm{~h}$ sampling period, either a SonTek Triton ADV (averaging interval 1 min,

203 sampling interval $10 \mathrm{~min} ; \sim 65 \mathrm{~cm}$ above seafloor; deployed in Win, Spr, Sum) or a

204 SonTek Argonaut ADCP (XR 3000 kHz; averaging interval 2 min, sampling interval 5

205 min; $20 \mathrm{~cm}$ above seafloor; deployed in Aut) was positioned in the centre of the Pepe Inlet

206 channel to measure current velocity. A Solinist Levelogger (measuring absolute water

207 pressure) was placed in the centre of the channel to measure water depth, and a Solinist

208 Barologger was used to compensate the depth obtained by the Levelogger for barometric

209 pressure (sampling interval $10 \mathrm{~min}$.). The cross-sectional area and water velocity was

210 measured using a SonTek FlowTracker Handheld ADV to calculate discharge (0.6 depth

211 and multipoint methods; Sontek/YSI Inc. 2007), approximately hourly during the daylight

212 hours.

213 Laboratory analyses

214 Plant detritus collected by the nets was washed, separated by source (e.g. mangrove,

215 seagrass, terrestrial/marsh, macroalgae), dried to constant weight at $60^{\circ} \mathrm{C}$, and weighed

216 (dry weight, DW). Half hourly filtered water samples were pooled in the laboratory across 
217 one hour and subsamples taken for measurements of TDN, TDP, and ammonium $\left(\mathrm{NH}_{4}^{+}\right)$

218 on a LACHAT Quickchem 8500 series 2 Flow Injection Analyser (FIA). $\mathrm{NO}_{\mathrm{x}}$ and $\mathrm{PO}_{4}{ }^{2-}$

219 were also measured, but results were unreliable and data are not presented. TDN consists

220 of dissolved $\mathrm{NH}_{4}{ }^{+}+\mathrm{NO}_{\mathrm{x}}+$ organic $\mathrm{N}$, and TDP consists of dissolved $\mathrm{PO}_{4}{ }^{2-}+\operatorname{organic} \mathrm{P}$,

221 but the proportions of $\mathrm{NO}_{\mathrm{x}}$ and $\mathrm{PO}_{4}{ }^{2-}$, as well as dissolved organic $\mathrm{N}$ and $\mathrm{P}$ are unknown.

222 Water samples for TDN and TDP, and filters for TPN and TPP (one filter for each two

223 hourly sampling) were first digested (potassium persulphate solution) and autoclaved (30

$224 \min$ at $121^{\circ} \mathrm{C}, 15 \mathrm{psi}$ ), before analysis of total $\mathrm{N}$ and $\mathrm{P}$ on the FIA. Water column

225 particulate chl $a$ concentrations were determined by steeping and grinding filters (two

226 filters for each half hour sampling) in $90 \%$ buffered acetone, and then pigment

227 concentrations were measured fluorometrically (Turner 10-AU fluorometer) before and

228 after acidification (Arar and Collins 1997).

229 Data analysis and material flux calculations

230 A linear correlation between the discrete discharge measurements (Flowtracker ADV

231 during the day) and the continuous water velocity $\times$ depth (5-10 min measurement

232 interval) was used to predict discharge over the $24 \mathrm{~h}$ sampling period (correlation $\mathrm{r}^{2}=$

233 0.84-0.94; see Fig. A2 in Appendices for correlations). The total discharge volume for

234 each flood and ebb tide was then estimated by summing the predicted discharge rate at 10

235 min intervals within each tidal stage (Fig. A3, and Table A2).

236 TDN, TDP, TPN, TPP, and chl $a$ concentrations averaged over the $4 \mathrm{~h}$ of peak flow

237 (estimated from velocity measurements) were used to calculate the fluxes from Pepe Inlet,

238 where the $4 \mathrm{~h}$ average concentration was multiplied by the discharge volume for each ebb

239 and flood tide. Using the mean annual discharge from Pepe Stream $\left(0.23 \mathrm{~m}^{3} \mathrm{~s}^{-1}\right.$; Liu 2014;

240 which is $<1 \%$ of the peak discharge measured at the mouth of Pepe Inlet), we estimated 
241 the input of TDN, TDP, TPN, TPP, and chl $a$ from Pepe Stream into Pepe Inlet over a tidal

242 cycle (i.e. stream input $=$ stream discharge scaled to a tidal cycle $\times$ average solute or

243 particulate concentration measured at Pepe Stream). As all sampling periods fell during

244 periods of low rainfall (i.e. there was $<13 \mathrm{~mm}$ of rain in the $24 \mathrm{~h}$ prior to and during

245 sampling), we consider the mean annual discharge suitable for estimating stream inputs.

246 Fluxes of macrodetritus were calculated by summing the total detritus DW collected in the

247 nets during each flood and ebb tide, and this total was multiplied by the width of the

248 channel (i.e. macrodetritus flux $=$ total detritus $\mathrm{DW} \times 37 \mathrm{~m} / 2 \mathrm{~m}$ sampling width of nets;

249 similar flux calculations are described in Bouchard and Lefeuvre 2000). This calculation

250 assumes that our nets sample the entire water column throughout the tidal cycle; a

251 reasonable assumption given that just $\sim 0.6 \mathrm{~m}$ of the water column was omitted during high

252 tide, but during times of peak flow (mid-tide) the entire water column was sampled by the

253 nets. Further, the top and the bottom nets captured the majority of the macrodetritus

$254(>72 \%$, but usually $>90 \%$ of the total collected macrodetritus), suggesting that detritus

255 usually either floats or is transported along the seafloor, and little was caught suspended in

256 the middle of the water column. To estimate the flux of macrodetritus $\mathrm{N}$ and $\mathrm{P}$, and to

257 allow comparisons with other sources (dissolved and particulate), detrital DW was

258 converted to $\mathrm{N}$ and $\mathrm{P}$ using the average values (as \% of DW) for each detrital source (or

259 similar sources) from the Enriquez et al. (1993) review, as well as from $\mathrm{N}$ content

260 measured for Z. muelleri, A. marina, and E. radiata in Gladstone-Gallagher et al. (2016).

261 Results

262 Across sampling dates, the channel at the mouth of Pepe Inlet remained well mixed for

$263 \sim 75 \%$ of the tidal cycle (determined from hourly depth profiles of salinity, temperature and

264 DO in the channel), only becoming stratified for $\sim 3 \mathrm{~h}$ at slack low tide when tidal 
exchange was minimal. The difference in salinity between the bottom and surface waters during this low tide stratification (i.e. channel depth $\sim 0.7-0.9 \mathrm{~m}$ ) was $<14.2 \mathrm{ppt}$, with

267 temperature and DO differences of $<2.9^{\circ} \mathrm{C}$ and $<2.2 \mathrm{mg} \mathrm{L}^{-1}$, respectively. During the 268 remainder of the tidal cycle, when the water column was well mixed (i.e. channel depth $269 \sim 0.9-2.2 \mathrm{~m}$ ), salinity differences between the bottom and surface waters were <4.9 ppt (but 270 often $<0.5 \mathrm{ppt}$ ), with surface vs. bottom water differences in temperature $<1.9^{\circ} \mathrm{C}$ (but often $\left.271<0.5^{\circ} \mathrm{C}\right)$, and DO $<0.68 \mathrm{mg} \mathrm{L}^{-1}$. Across the sampling dates, salinity averaged across the 272 tidal cycle ranged from $24.2-31.6 \mathrm{ppt}$, temperature from $11.4-20.3^{\circ} \mathrm{C}$, and DO

273 concentration from 7.5-9.3 $\mathrm{mg} \mathrm{L}^{-1}$.

\section{Macrodetritus fluxes}

275 The magnitude of the flood and ebb macrodetritus fluxes varied across seasons, by both 276 weight and source (Fig. 2). Seagrass (Z. muelleri) was the dominant detrital source to be

277 transported by flood tides in all seasons (40-92\% of flood fluxes). In Spr and Sum, 278 macroalgae (including unidentified green and brown species) were equally dominant, 279 contributing 49 and $36 \%$ to the Spr and Sum flood tide fluxes, respectively. Ebb tide 280 macrodetrital transport was highly seasonal and dominated by mangrove litter (A. marina) 281 in Spr (61\% of the ebb flux), but by seagrass in Aut and Win (39 and 52\%, respectively), 282 and macroalgae in Sum (38\%). The transport of terrestrial/marsh detritus (broadly grouped 283 and not identified to species level) was consistent across seasons in terms of absolute 284 contribution (0.1-5.3 kg DW tide $\mathrm{k}^{-1}$ on both flooding and ebbing tides), but varied across 285 seasons in relative contribution to the total macrodetritus fluxes (Ebb fluxes: 50\% Aut, $28632 \%$ Win, 16\% Spr, 19\% Sum; Flood fluxes: 4\% Aut, 33\% Win, 6\% Spr, 12\% Sum; Fig. 287 2). 
288 The net fluxes of macrodetritus (ebb flux minus flood flux) show that Pepe Inlet acted as a 289 net exporter of macrodetritus on three of the four sampling dates (Aut, Win, and Sum; Fig.

290 2). The greatest export occurred in Sum, where nearly $10 \mathrm{~kg} \mathrm{DW}$ tidal cycle ${ }^{-1}$ of

291 macrodetritus was exported from Pepe Inlet. The Sum macrodetritus export was comprised 292 of $43 \%$ macroalgae, $33 \%$ terrestrial/marsh, $17 \%$ seagrass, and $7 \%$ mangrove detritus. In

293 Aut, the small net export was largely made up of terrestrial/marsh litter (83\%), and in Win,

294 the export was comprised equally of the four sources (i.e. mangrove, seagrass,

295 terrestrial/marsh, and macroalgae all contributed $20-30 \%$ of the net export). In Spr there

296 was a net import into the inlet (11 kg DW tidal cycle $\left.{ }^{-1}\right)$, which was predominantly

297 comprised of seagrass and macroalgae (Fig. 2) and juxtaposed against a small export of

298 mangrove detritus ( $1.6 \mathrm{~kg}$ tidal $\left.\mathrm{cycle}^{-1}\right)$. Using the average of the net fluxes across seasons,

299 it is estimated that $\sim 449 \mathrm{~kg} \mathrm{DW} \mathrm{yr}^{-1}$ of macrodetritus is exported from Pepe Inlet, or $30 \mathrm{~kg}$

300 DW ha ${ }^{-1} \mathrm{yr}^{-1}$ when scaled to the area occupied by marine vegetated habitats $(\sim 15$ ha of

301 mangroves, seagrass and saltmarsh) within Pepe Inlet. In Sum and Win, the net fluxes

302 were relatively small compared to the total ebb or flood fluxes (net fluxes $18-34 \%$ and 22-

$30352 \%$ of the total flood and ebb flux, respectively).

304 Nitrogen fluxes

305 The dominant form of $\mathrm{N}$ transported by both flooding and ebbing tides was TDN, which

306 comprised $>94 \%$ of the total fluxes in Aut, Win and Spr. In Sum, TDN was lower and

307 comprised 80 and $85 \%$ of $\mathrm{N}$ on ebb and flood tides, respectively (Fig. 3). TDN fluxes

308 consisted of 6-28\% $\mathrm{NH}_{4}^{+}$(compare Fig. 3C with D), with the proportion of $\mathrm{NO}_{\mathrm{x}}$ and

309 organic $\mathrm{N}$ unknown. Across seasons, macrodetritus contributed $<3 \%$ to the total $\mathrm{N}$ flux on

310 both flood and ebb tides. In Aut, Win, and Spr, TPN contributed $<5 \%$ to the total $\mathrm{N}$ fluxes, 
311 whereas, in Sum, when TDN fluxes were lower, the TPN comprised 13 and 17\% of flood

312 and ebb tide fluxes, respectively (Fig. 3).

313 Across seasons, Pepe Inlet was a net exporter of N (dissolved and particulate $\mathrm{N}$ exports

314 offset macrodetritus imports in Spr), exporting a total of $2-12 \mathrm{~kg} \mathrm{~N}$ tidal cycle ${ }^{-1}$. The

315 dominant form of $\mathrm{N}$ exported in Aut, Win and Spr was dissolved (TDN $>93 \%$ of the total

316 net $\mathrm{N}$ exports). Macrodetritus and particulate matter contributed relatively little to the total

317 net $\mathrm{N}$ export $(<7 \%)$, except for in Sum where dissolved fluxes were low, and macrodetritus

318 and particulate $\mathrm{N}$ contribution were 13 and $66 \%$ of the net $\mathrm{N}$ export, respectively (Fig. 3).

319 Annual estimates of net $\mathrm{N}$ fluxes are $6 \mathrm{~kg} \mathrm{~N} \mathrm{yr}^{-1}$ imported as macrodetritus, $467 \mathrm{~kg} \mathrm{~N} \mathrm{yr}^{-1}$

320 exported as particulates, and $4684 \mathrm{~kg} \mathrm{~N} \mathrm{yr}^{-1}$ exported as dissolved (total annual $\mathrm{N}$ export = $3215145 \mathrm{~kg} \mathrm{~N})$.

322 Phosphorus fluxes

323 In Aut and Spr, P fluxes transported by both flood and ebb tides were dominated by TDP

324 (TDP contribution in Aut $=74-82 \%$, and $\mathrm{Spr}=82-87 \%$ of total $\mathrm{P}$ fluxes). Whereas, in Win

325 and Sum, P fluxes transported in both flood and ebb tides were dominated by TPP (TPP

326 contribution in Win $=51-55 \%$, and Sum $=87 \%$ of total $\mathrm{P}$ fluxes $)$. Across seasons,

327 macrodetritus contributed relatively little to the total P fluxes of both flood and ebb tides

328 (<13\%; Fig. 4).

329 In Win, Spr, and Sum, Pepe Inlet acted as a net exporter of P (macrodetritus imports in Spr

330 were offset by TDP and TPP exports), exporting a total of $0.5-1.5 \mathrm{~kg} \mathrm{P}$ tidal cycle ${ }^{-1}$, but in

331 Aut, Pepe Inlet imported $0.5 \mathrm{~kg} P$ tidal cycle ${ }^{-1}$. In Win (when all forms of $\mathrm{P}$ were exported

332 from Pepe Inlet), macrodetritus, TDP, and TPP represented 2.3, 57.2, and 40.4\% of the

333 total net export of P, respectively (Fig. 4). Annual estimates of net $\mathrm{P}$ fluxes are $8 \mathrm{~kg} \mathrm{P} \mathrm{yr}^{-1}$ 
334 imported as macrodetritus, $164 \mathrm{~kg} \mathrm{P} \mathrm{yr}^{-1}$ exported as particulates, and $206 \mathrm{~kg} \mathrm{P} \mathrm{yr}^{-1}$

335 exported as dissolved material (total annual export $=362 \mathrm{~kg} \mathrm{P}$ ).

336 Chlorophyll $a$ fluxes

337 Pepe Inlet was a net exporter of $\operatorname{chl} a$ (i.e. particulate chl $a$ captured on filters), where 35-

$338146 \mathrm{~kg}$ tidal cycle ${ }^{-1}$ of chl $a$ was exported from the inlet (except in Spr where $14 \mathrm{~kg}$ tidal

339 cycle $^{-1}$ of chl $a$ was imported; Fig. 5). Annually, it is estimated that Pepe Inlet exports

$340 \quad 39,145 \mathrm{~kg}$ particulate $\mathrm{chl} a$.

\section{Stream contribution to net fluxes}

342 The contribution of nutrients and chl $a$ from Pepe Stream was seasonally variable, and 343 contributed $10-42 \%$ of the total N, and $10-19 \%$ to the total P exports at the mouth of Pepe

344 Inlet (Table 1). In Aut, the stream contributed 20-55\% to the exports of TDN, TDP, TPN,

345 TPP, and chl $a$ measured at the mouth of the Inlet, but in Win, the stream contributed less

346 to these material exports (just 6-19\% of the net exports were from the stream). In Spr, the

347 stream inputs of TDN and TDP were low ( 8 and 4\%, respectively), while inputs of TPN

348 and TPP were relatively high (51 and 74\%, respectively). In Sum, Pepe Stream inputs

349 accounted for $10-44 \%$ of the material exports from Pepe Inlet, except for TDN, where the

350 input from the stream was almost double the net export out of Pepe Inlet (Table 1).

351 Discussion

352 As empirical measurements of macrodetritus fluxes from temperate estuaries are rare and

353 often excluded from estuarine nutrient budgets, this study was designed to quantify the

354 relative contribution of macrodetritus to the overall estuary-to-coast flux of primary

355 production, $\mathrm{N}$ and $\mathrm{P}$. We found that across most seasons, Pepe Inlet was a net exporter of 
macrodetritus, chl $a$, as well as total $\mathrm{N}$ and $\mathrm{P}$. The dissolved and small particulate fractions dominated the net fluxes of total $\mathrm{N}$ and $\mathrm{P}$ from Pepe Inlet. Given that coastal marine primary production is regulated by both $\mathrm{N}$ and $\mathrm{P}$, with dissolved $\mathrm{N}$ often being the limiting nutrient (Herbert 1999; Tyrell 1999), estuaries including Pepe Inlet potentially play an

360 important role as exporters of nutrients, supporting production in the open coastal ocean.

361 Whilst the contribution of macrodetritus to the $\mathrm{N}$ and $\mathrm{P}$ export out of the inlet was small 362 ( $<13 \%$ and $<3 \%$ of $\mathrm{N}$ and $\mathrm{P}$ exports, respectively, across seasons, except for spring where macrodetritus was imported), macrodetritus flux was relatively large in terms of DW. As macrodetritus is an obvious and visible source of estuarine primary production, its degradation and accumulation in receiving habitats (e.g. coastal soft-sediments, seagrass beds and other vegetated habitats) has the potential to alter ecosystem structure and

367 function (e.g. by structuring macrofaunal communities; Kelaher and Levinton 2003; Rossi 2006; Bishop et al. 2010).

369 Scaling up the macrodetritus weights to estimate the amount of litter that is exported

370 annually from Pepe Inlet yields $\sim 30 \mathrm{~kg} \mathrm{DW} \mathrm{ha}^{-1}$ of vegetated area within the inlet $(\sim 15 \mathrm{ha}$

371 of seagrass, mangroves and marsh habitat). This estimate is comparable to the

372 macrodetritus export that was measured in the mangrove basin, Tuff Crater, New Zealand

373 (7-42 $\mathrm{kg} \mathrm{DW} \mathrm{ha}^{-1} \mathrm{yr}^{-1}$ when converted to area of vegetation; Woodroffe 1985), and

374 although hydrodynamically different, Tuff Crater is similar in area to Pepe Inlet. In

375 addition, our estimated annual export of macrodetritus is also comparable to that of North

376 Inlet (USA), which was found to export $27 \mathrm{~kg} \mathrm{DW} \mathrm{ha}^{-1}$ of saltmarsh annually (annual

377 export scaled to saltmarsh area; Dame and Stilwell 1984; Dame et al. 1986). Others have

378 found lower macrodetritus exports than Pepe Inlet, which is likely related to the specific

379 hydrodynamics of the systems in question, being temperate marsh systems that have high 
water residence times and less frequent tidal inundation (Table A1; Hemminga et al. 1996;

381 Bouchard and Lefeuvre 2000).

382 In their review of estuary-to-coast flux studies, Childers et al. (2000) used regression

383 analysis ( $\mathrm{n}=20$ studies) to identify the physical factors regulating dissolved and

384 particulate material transport across estuarine to open ocean boundaries. Tidal range

385 explained $40 \%$ of the variation in dissolved nutrient flux, where systems switched from

386 importers to exporters at tidal ranges $>1.2 \mathrm{~m}$ (similar results were also found by Adame

387 and Lovelock 2011, when reviewing the hydrological factors that affect nutrient export

388 from mangrove forests). The extensive review also found that smaller estuaries ( $<54 \mathrm{ha})$

389 showed greater exports of particulate organic matter. Tairua Estuary not only has a high

390 tidal exchange (82\% of water exchanged each tide; Bell 1994) and range (1.2-1.6 m), but

391 is regarded as a small estuary ( $<54$ ha). Further, the majority of vegetated habitats in Pepe

392 Inlet (seagrass and mangroves, as well as some of the marsh) occur below the mean high

393 water spring tide mark, which is likely to increase the opportunity for material exports out

394 of these systems. These hydrodynamic properties will undoubtedly influence the exchange

395 of macrodetritus, and to some extent limit the generalisability of our results to other

396 temperate estuaries (i.e. larger salt marsh systems that have more limited tidal exchange).

397 However, Pepe Inlet represents a common estuary type, at least in the New Zealand

398 context (Hume et al. 2007), in that it is a largely intertidal, ebb-dominated (Fig. A3 in

399 Appendices), mixed habitat estuary.

400 Whilst Pepe Inlet annually exported macrodetritus in terms of total DW, it was found to be

401 a net importer of macrodetritus $\mathrm{N}$ and $\mathrm{P}$ on an annual basis (imports $=6 \mathrm{~kg} \mathrm{~N} \mathrm{yr}^{-1}$ and $8 \mathrm{~kg}$

$402 \mathrm{P} \mathrm{yr}^{-1}$; Table A1). The $\mathrm{N}$ and $\mathrm{P}$ content of macrodetritus depends on the plant species;

403 macroalgae are $1.0-3.9 \% \mathrm{~N}$ and $0.2-0.4 \% \mathrm{P}$, while mangrove litter contains $0.7-1.2 \% \mathrm{~N}$ 
total macrodetritus flux in terms of total DW does not distinguish between the differences in detrital species composition on the ebbing and flooding tides, where the imports into

Pepe Inlet were generally dominated by macroalgae and seagrass, and exports were dominated by mangrove and terrestrial/marsh leaf litter. Thus, the resulting annual flux of macrodetritus $\mathrm{N}$ and $\mathrm{P}$ were imports (i.e. imports of relatively $\mathrm{N}$ and $\mathrm{P}$ rich macrodetritus offset exports of relatively $\mathrm{N}$ and $\mathrm{P}$ poor macrodetritus). On an annual basis, Pepe Inlet

411 acts as a net importer of macrodetritus $\mathrm{N}$ and $\mathrm{P}$ (albeit minimal), but an exporter of other

412 forms of $\mathrm{N}$ and $\mathrm{P}$ (particulates and dissolved), suggesting the potential role of these

413 estuaries as organic matter transformers. It is also worth noting that, in Pepe Inlet, the

414 individual flood and ebb macrodetritus fluxes were often much higher than net fluxes (net

415 fluxes $18-52 \%$ of the total flood/ebb flux in summer and winter), suggesting that some of

416 the macrodetritus transported out of the estuary probably returns with the subsequent

417 flooding tide (i.e. macrodetritus is transported in large volumes, but the net export is

418 relatively small by comparison). This returning detritus can also become trapped within the

419 vegetated habitats in the estuary (e.g. seagrass beds and mangrove forest), increasing

420 retention and limiting export out of the estuarine system (Gillis et al. 2014).

421 Fluxes of all forms of $\mathrm{N}$ and $\mathrm{P}$ varied across seasons. Most markedly was the difference in summer (compared to other seasons), where macrodetritus and chl $a$ transport (and export) 423 peaked, and dissolved $\mathrm{N}$ and $\mathrm{P}$ dropped. The summer peak in macrodetritus transport is not 424 surprising given that many marine plants show seasonal peaks in growth and production in 425 summer, which could also promote dissolved inorganic nutrient uptake by macrophytes 426 (potentially explaining the lower dissolved nutrient exports in summer). New Zealand mangroves produce $77 \%$ of their total litter production between November and February 428 (Gladstone-Gallagher et al. 2014). In addition, macroalgae senescence and erosion, and 
seagrass growth and production, can also be greatest in summer (Brown et al. 1997;

430 Turner 2007). However, when organic matter is imported into the estuary (e.g.

431 macrodetritus in spring), or when exports are low (i.e. high retention of macrodetritus),

432 decay and remineralisation processes will occur within the estuary. If in situ decay and

433 organic matter transformations are high, then outwelled production may be in the form of

434 dissolved inorganic nutrients rather than organic detritus.

435 Organic matter transformations that occur within the estuary are likely to modify the form

436 in which production and nutrients are outwelled, and they may help to explain some of the

437 seasonal fluctuations in $\mathrm{N}$ and P fluxes. In Pepe Inlet, the contribution of the stream was

438 seasonally variable, contributing between $10-55 \%$ of the estuary's total N, P and chl $a$

439 exports. Analysing each form of $\mathrm{N}$ and $\mathrm{P}$ separately revealed some interesting results, for

440 example, the summer input of TDN from Pepe Stream was $1.5 \times$ greater than the TDN

441 exported from Pepe Inlet. However, for total N (i.e. TDN + TPN + macrodetritus N), Pepe

442 Stream only contributed $42 \%$ to the total N exported (Table 1). This further indicates that

443 processes within the estuary transform and utilise some of this dissolved $\mathrm{N}$ before it can be

444 exported at the estuary mouth. As the net export of chl $a$ was also highest in summer, the

445 dissolved inorganic $\mathrm{N}$ may be utilised by in situ phytoplankton and microphytobenthos

446 during summer, exporting $\mathrm{N}$ as particulate organic $\mathrm{N}$.

447 Our study design did not detail within-estuary processes, and instead focused on the 448 differences between measured inputs (at Pepe Stream) and outputs (at the mouth of Pepe

449 Inlet). Nevertheless, processes within the estuary can be discussed, in an attempt to

450 illuminate the simple 'black box' model (depicted in Fig. 6). In summer and winter, $>67 \%$

451 of the net exports of macrodetritus were from marine sources, and therefore it is likely that

452 this production mostly occurred within the inlet itself, rather than transported by the stream 
453 (although the terrestrial/marsh sources were important in autumn). Other processes within

454 the estuary, including the solute fluxes across the sediment-water interface, are likely to

455 contribute to the export of nutrients from the inlet. In temperate estuaries, sediment-water

456 effluxes of dissolved inorganic $\mathrm{N}\left(\mathrm{NO}_{\mathrm{x}}\right.$ and $\left.\mathrm{NH}_{4}{ }^{+}\right)$and $\mathrm{P}\left(\mathrm{PO}_{4}{ }^{2-}\right)$ occur through nutrient

457 remineralisation processes in the benthos (e.g. Lohrer et al. 2004; Pratt et al. 2014). It is

458 estimated that up to $50 \%$ of global organic matter remineralisation occurs in the coastal

459 soft-sediments (Middelburg et al. 1997), and therefore these sediments may supply

460 dissolved $\mathrm{N}$ and $\mathrm{P}$ to the water column that is available to be outwelled to the adjacent

461 coastal waters.

462 In a previous study, we measured summertime sediment-water solute fluxes of $\mathrm{NH}_{4}{ }^{+}$in

463 Pepe Inlet (Gladstone-Gallagher et al. 2017), and since $\mathrm{NH}_{4}{ }^{+}$is the dominant form of

464 dissolved inorganic $\mathrm{N}$ that is moved out of the sediments ( $>88 \%$ of inorganic $\mathrm{N}$ efflux;

465 Thrush et al. 2006; Jones et al. 2011; Pratt et al. 2014; Gladstone-Gallagher et al. 2016),

466 these fluxes can be used to estimate the contribution of the unvegetated sediments to the

467 export of N. Using the summertime measurements in Pepe Inlet, we estimate that on

468 average $\sim 0.7 \mathrm{~kg}$ of $\mathrm{N}$ tidal cycle ${ }^{-1}$ comes from the sediments in the form of $\mathrm{NH}_{4}^{+}$,

469 accounting for $\sim 40 \%$ of the total $\mathrm{N}$ exported (Fig. 6). To explore this same $\mathrm{N}$ budget

470 model for the other seasons, we used the $\mathrm{NH}_{4}{ }^{+}$flux values from Pratt et al. (2014), who

471 measured benthic ecosystem function across nine estuaries in different seasons (Table 2).

472 Based on maximum benthic $\mathrm{NH}_{4}{ }^{+}$fluxes documented in Pratt et al. (2014; scaled to the

473 area of Pepe Inlet), it is plausible that in autumn and summer, the benthic fluxes could

474 account for the differences in inputs and outputs of $\mathrm{N}$ in Pepe inlet $(0.46 \mathrm{~kg}$ and $0 \mathrm{~kg} \mathrm{~N}$

475 unaccounted for in autumn and summer, respectively). However, in winter and spring

476 some $\mathrm{N}$ is unaccounted for by this budget (3.29 and $5.67 \mathrm{~kg} \mathrm{~N}$ tidal cycle ${ }^{-1}$, respectively;

477 Table 2). The sources of $\mathrm{N}$ contributing to this shortfall remain unknown, but could be 
associated with seasonal differences in rainfall and groundwater discharge (Santos et al. 2012; Santos et al. 2014). Benthic $\mathrm{NH}_{4}{ }^{+}$fluxes may be outwelled as $\mathrm{NH}_{4}{ }^{+}$, but may also be utilised within the estuary (e.g. by in situ phytoplankton production) and exported in another form. This has been suggested for dissolved $\mathrm{C}$ and $\mathrm{N}$ in the North Inlet estuary

482 (saltmarsh-dominated inlet), where it is thought that dissolved nutrients are rapidly utilised within the estuary and instead exported as particulates (Dame et al. 1986). Whilst our calculations do not account for the contribution of $\mathrm{NO}_{\mathrm{x}}$ or $\mathrm{PO}_{4}{ }^{2-}$ from the sediments, the analysis highlights that the benthos is likely to represent a significant source of outwelled nutrients (Fig. 6; Table 2).

Seasonal flux differences may be confounded by differences in the lunar cycle stage during times of sampling (i.e. some variability in the tidal amplitude was inevitable; Table A2), which has particular consequences for overestimating the transport of terrestrial and marsh production. Other limitations of our flux estimates include the simplification of macrodetritus flux estimates to omit variability in flow conditions across the channel width; small differences in the accuracy of the model used to predict discharge between

493 the different sampling dates (Fig.A2); the omission of storm/flood conditions from 494 sampling (i.e. such conditions would result in increased transport of materials particularly from the terrestrial habitat); and the potential effects of the small-scale temporal variability in abiotic factors (e.g. wind speed/direction and stream flow conditions) confounding the

497 perceived seasonal variability in detrital transport.

This study provides real-world quantification of the magnitude of macrodetritus fluxes, as well as the simultaneous measurements of other forms of production exported from a

500 typical temperate New Zealand estuary. Data of this type can be useful to inform studies of estuarine food webs, nutrient budgets, and the ecosystem services provided by temperate 
estuaries, which are important when predicting ecosystem effects of anthropogenic degradation of marine habitats. Whilst macrodetritus represents a relatively minor source

504 of $\mathrm{N}$ and $\mathrm{P}$, its transport (here up to $10 \mathrm{~kg}$ net tidal cycle ${ }^{-1}$ ) and accumulation in large

505 patches will have important effects on receiving ecosystems. Examples include its effects

506 in structuring benthic infaunal communities (e.g. Kelaher and Levinton 2003; Bishop and

507 Kelaher 2007), or its role in modifying ecosystem function in receiving habitats (e.g.

508 Gladstone-Gallagher et al. 2016). Because detritus is transported in relatively large

509 quantities, and it decays slowly, it may represent an important source of primary

510 production to offshore, deeper food webs that have low in situ productivity (e.g. sediments

511 below the photic zone; Britton-Simmons et al. 2009). Our results also emphasise the role

512 of temperate estuaries as sites of efficient organic matter transformation, where there is a

513 net export of total $\mathrm{N}$ and $\mathrm{P}$, but when broken down into the various components of material

514 transport, some materials are imported (e.g. macrodetritus in spring), but processed within

515 the estuary and exported in a different form (e.g. dissolved N).

\section{Acknowledgements}

517 We thank Dudley Bell, Warrick Powrie, Chris Morcom, Bradley Monahan, Emily

518 Douglas, Clarisse Niemand, Ryan Hughes, Catherine Kelly, Holly Bredin-Grey, Katie

519 Brasell, and Mathew Bennion for helping with field work, Ronald Ram for laboratory

520 assistance, Ben Norris, Bradley Monahan, and Berengere Dejeans for data analysis advice,

521 and Hazel Needham for providing helpful advice during sampling design planning. We

522 also acknowledge and thank an anonymous reviewer who greatly improved the

523 manuscript. 
524 This project was supported by a University of Waikato Doctoral Scholarship, Shirtcliffe

525 Fellowship, Waikato Graduate Women Charitable Trust Merit Award for Doctoral Study, 526 and New Zealand Coastal Society PhD scholarship to RVGG.

527 The authors declare no conflicts of interest. 


\section{References}

529

530

Adame, M. F., and Lovelock, C. E. (2011). Carbon and nutrient exchange of mangrove forests with the coastal ocean. Hydrobiologia 663, 23-50.

Arar, E. J., and Collins, G. B. (1997). Method 445.0: In vitro determination of chlorophyll $a$ and pheophytin $a$ in marine and freshwater algae by fluorescence. (U.S. Environmental Protection Agency: Cincinnati, Ohio, USA)

Baird, D., Winter, P. E. D., and Wendt, G. (1987). The flux of particulate material through a well-mixed estuary. Continental Shelf Research 7, 1399-1403.

Barbier, E. B., Hacker, S. D., Kennedy, C., Koch, E. W., Stier, A. C., and Silliman, B. R. (2011). The value of estuarine and coastal ecosystem services. Ecological Monographs 81, 169-193.

Bell, R. G. (1994). Behaviour of dissolved silica, and estuarine/coastal mixing and exchange processes at Tairua Harbour, New Zealand. New Zealand Journal of Marine and Freshwater Research 28, 55-68.

Biber, P. D. (2007). Hydrodynamic transport of drifting macroalgae through a tidal cut. Estuarine, Coastal and Shelf Science 74, 565-569.

Bishop, M. J., Coleman, M. A., and Kelaher, B. P. (2010). Cross-habitat impacts of species decline: response of estuarine sediment communities to changing detrital resources. Oecologia 163, 517-525. 
547 Bishop, M. J., and Kelaher, B. P. (2007). Impacts of detrital enrichment on estuarine assemblages: disentangling effects of frequency and intensity of disturbance. Marine Ecology Progress Series 341, 25-36.

Borey, R. B., Harcombe, P. A., and Fisher, F. M. (1983). Water and organic carbon fluxes from an irregularly flooded brackish marsh on the upper Texas coast, U.S.A. Estuarine, Coastal and Shelf Science 16, 379-402.

553

554

555

556

557

558

559

560

561

562

563

564

565

566

567

Boto, K. G., and Bunt, J. S. (1981). Tidal export of particulate organic-matter from a Northern Australian mangrove system. Estuarine, Coastal and Shelf Science 13, 247-255.

Boto, K. G., and Wellington, J. T. (1988). Seasonal-variations in concentrations and fluxes of dissolved organic and inorganic materials in a tropical, tidally-dominated, mangrove waterway. Marine Ecology Progress Series 50, 151-160.

Bouchard, V., and Lefeuvre, J. C. (2000). Primary production and macro-detritus dynamics in a European salt marsh: carbon and nitrogen budgets. Aquatic Botany 67(1), 2342.

Britton-Simmons, K. H., Foley, G., and Okamoto, D. (2009). Spatial subsidy in the subtidal zone: utilization of drift algae by a deep subtidal sea urchin. Aquatic Biology 5, 233-243.

Brown, T. M., Nyman, A. M., Keogh, A. J., and Chin, M. N. K. (1997). Seasonal growth of the giant kelp Macrocystis pyrifera in New Zealand. Marine Biology 129, 417424. 
568 Childers, D. L., Day, J. W. J., and McKellar, H. N. J. (2000). Twenty more years of marsh and estuarine flux studies: revisiting Nixon (1980). In 'Concepts and controversies in tidal marsh ecology'. (Eds M. P. Weinstein and D. A. Kreeger) pp. 391-423. (Springer Netherlands.)

Dame, R., Chrzanowski, T., Bildstein, K., Kjerfve, B., McKellar, H., Nelson, D., Spurrier, J., Stancyk, S., Stevenson, H., Vernberg, J., and Zingmark, R. (1986). The outwelling hypothesis and North Inlet, South-Carolina. Marine Ecology Progress Series 33, 217-229.

Dame, R. F. (1982). The flux of floating macrodetritus in the North Inlet estuarine ecosystem. Estuarine, Coastal and Shelf Science 15, 337-344.

Dame, R. F., and Allen, D. M. (1996). Between estuaries and the sea. Journal of Experimental Marine Biology and Ecology 200, 169-185.

Dame, R. F., and Stilwell, D. (1984). Environmental factors influencing macrodetritus flux in North Inlet estuary. Estuarine, Coastal and Shelf Science 18, 721-726.

Dankers, N., Binsbergen, M., Zegers, K., Laane, R., and Vanderloeff, M. R. (1984). Transportation of water, particulate and dissolved organic and inorganic matter between a salt-marsh and the Ems-Dollard Estuary, The Netherlands. Estuarine, Coastal and Shelf Science 19, 143-165.

Doi, H., Matsumasa, M., Fujikawa, M., Kanou, K., Suzuki, T., and Kikuchi, E. (2009). Macroalgae and seagrass contribution to gastropods in sub-tropical and temperate tidal flats. Journal of the Marine Biological Association of the United Kingdom 89, 399-404. 
590 Enriquez, S., Duarte, C. M., and Sandjensen, K. (1993). Patterns in decomposition rates among photosynthetic organisms: the importance of detritus $\mathrm{C}: \mathrm{N}: \mathrm{P}$ content. Oecologia 94, 457-471.

593

Eyre, B., and Balls, P. (1999). A comparative study of nutrient behavior along the salinity gradient of tropical and temperate estuaries. Estuaries 22, 313-326.

Felsing, M., and Giles, H. (2011). Tairua Estuary shellfish and benthic habitat mapping and assessment of sediment contamination (2009/10). Waikato Regional Council Technical Report 2011/31, Hamilton, New Zealand.

Gillis, L. G., Bouma, T. J., Kiswara, W., Ziegler, A. D., and Herman, P. M. J. (2014). Leaf transport in mimic mangrove forests and seagrass beds. Marine Ecology Progress Series 498, 95-102.

Gladstone-Gallagher, R. V., Lundquist, C. J., and Pilditch, C. A. (2014). Mangrove (Avicennia marina subsp. australasica) litter production and decomposition in a temperate estuary. New Zealand Journal of Marine and Freshwater Research 48, 24-37.

Gladstone-Gallagher, R. V., Lohrer, A. M., Lundquist, C. J., and Pilditch, C. A. (2016). Effects of detrital subsidies on soft-sediment ecosystem function are transient and source-dependent. PLoS ONE 11, e0154790.

Gladstone-Gallagher, R. V., Needham, H. R., Lohrer, A. M., Lundquist, C. J., and Pilditch, C. A. (2017). Site dependent effects of bioturbator-detritus interactions alter softsediment ecosystem function. Marine Ecology Progress Series 569, 145-161. 
611 Graeme, M. (2008). Estuarine Vegetation Survey - Tairua Harbour. Environment Waikato Technical Report 2008/52, Hamilton, New Zealand.

613 Granek, E. F., Compton, J. E., and Phillips, D. L. (2009). Mangrove-exported nutrient 614 incorporation by sessile coral reef invertebrates. Ecosystems 12, 462-472.

615 Harty, C. (2009). Mangrove planning and management in New Zealand and South East 616 Australia - A reflection on approaches. Ocean \& Coastal Management 52, 278617286.

618 Hemminga, M. A., Cattrijsse, A., and Wielemaker, A. (1996). Bedload and nearbed 619 detritus transport in a tidal saltmarsh creek. Estuarine, Coastal and Shelf Science 620 42, 55-62.

Herbert, R. A. (1999). Nitrogen cycling in coastal marine ecosystems. FEMS Microbiology 622 Reviews 23, 563-590.

Hume, T. M., and Herdendorf, C. E. (1993). On the use of empirical stability relationships for characterising estuaries. Journal of Coastal Research 9, 413-422.

Hume, T. M., Snelder, T., Weatherhead, M., and Liefting, R. (2007). A controlling factor 626 approach to estuary classification. Ocean \& Coastal Management 50, 905-929.

Imgraben, S., and Dittmann, S. (2008). Leaf litter dynamics and litter consumption in two 628 temperate South Australian mangrove forests. Journal of Sea Research 59, 83-93.

Inglis, G. J. (2003). Seagrasses of New Zealand. In 'World atlas of seagrasses'. (Eds E. P. 630 Green and F. T. Short) pp. 148-157. (University of California Press: Berkeley, California) 
632 Jones, H.F.E., Pilditch, C.A., Bruesewitz, D.A., Lohrer, A.M. (2011). Sedimentary

633

634

635

636

637

638

639

640

641

642

643

644

645

646

647

648

649

650

651

652

653 environment influences the effect of an infaunal suspension feeding bivalve on estuarine ecosystem function. PloS ONE 6, e27065.

Kelaher, B. P., and Levinton, J. S. (2003). Variation in detrital enrichment causes spatiotemporal variation in soft-sediment assemblages. Marine Ecology Progress Series 261, 85-97.

Liu, Z. (2014). Hydrodynamic and sediment transport numerical modelling and applications at Tairua Estuary, New Zealand. PhD thesis, University of Waikato, Hamilton, New Zealand.

Lohrer, A. M., Thrush, S. F., and Gibbs, M. M. (2004). Bioturbators enhance ecosystem function through complex biogeochemical interactions. Nature 431, 1092-1095.

Lohrer, A.M., Thrush, S.F., Hewitt, J.E., and Kraan, C. (2015). The up-scaling of ecosystem functions in a heterogeneous world. Scientific Reports 5, 10349.

Middelburg, J. J., Soetaert, K., and Herman, P. M. J. (1997). Empirical relationships for use in global diagenetic models. Deep Sea Research Part I: Oceanographic Research Papers 44, 327-344.

Moore, K. A., and Short, F. T. (2006). Zostera: Biology, ecology and management. In ‘Seagrasses: Biology, ecology and conservation'. (Eds A. W. D. Larkum, R. J. Orth and C. M. Duarte) pp. 363-380. (Springer: Dordrecht, The Netherlands)

Morrisey, D. J., Swales, A., Dittmann, S., Morrison, M., Lovelock, C. E., and Beard, C. M. (2010). The ecology and management of temperate mangroves. Oceanography and Marine Biology: An Annual Review 48, 43-160. 
654 Needham, H. R., Pilditch, C. A., Lohrer, A. M., and Thrush, S. F. (2011). Context-specific bioturbation mediates changes to ecosystem functioning. Ecosystems 14, 1096-

656 1109.

657

658

659

660

661

662

663

664

665

666

667

668

669

670

671

672

673

674

675

Nixon, S.W. (1980). Between coastal marshes and coastal waters - A review of twenty years of speculation and research on the role of salt marshes in estuarine productivity and water chemistry. In 'Estuarine and Wetland Processes'. (Eds P. Hamilton and K. B. Macdonald) pp. 437-525. (Springer US)

O'Donnell, E. (2011). Tairua Harbour and catchment management plan. Waikato Regional Council Technical Report 2011/40, Hamilton, New Zealand.

Odum, E.P. (1968). A research challenge: evaluating the productivity of coastal and estuarine water. In '2nd Sea Grant Conference'. pp. 63-64. (University of Rhode Island, Kingston)

Odum, E. P. (2000). Tidal marshes as outwelling/pulsing systems. In 'Concepts and Controversies in Tidal Marsh Ecology'. (Eds M. P. Weinstein and D. A. Kreeger) pp. 3-7. (Springer Netherlands)

Orth, R. J., Carruthers, T. J. B., Dennison, W. C., Duarte, C. M., Fourqurean, J. W., Heck, K. L., Hughes, A. R., Kendrick, G. A., Kenworthy, W. J., Olyarnik, S., Short, F. T., Waycott, M., and Williams, S. L. (2006). A global crisis for seagrass ecosystems. BioScience 56, 987-996.

Pergent, G., Rico-Raimondino, V., and Pergent-Martini, C. (1997). Fate of primary production in Posidonia oceanica meadows of the Mediterranean. Aquatic Botany 59, 307-321. 
676 Pratt, D. R., Lohrer, A. M., Pilditch, C. A., and Thrush, S. F. (2014). Changes in ecosystem function across sedimentary gradients in estuaries. Ecosystems 17, 182-194.

678

679

680

681

682

683

684

685

686

687

688

689

690

691

692

693

694

695

696

Rajkaran, A., and Adams, J. B. (2007). Mangrove litter production and organic carbon pools in the Mngazana Estuary, South Africa. African Journal of Aquatic Science 32, 17-25.

Ramos e Silva, C. A., Oliveira, S. R., Rêgo, R. D. P., and Mozeto, A. A. (2007). Dynamics of phosphorus and nitrogen through litter fall and decomposition in a tropical mangrove forest. Marine Environmental Research 64, 524-534.

Robertson, A. I. (1986). Leaf-burying crabs: their influence on energy-flow and export from mixed mangrove forests (Rhizophora spp) in Northeastern Australia. Journal of Experimental Marine Biology and Ecology 102, 237-248.

Rossi, F. (2006). Small-scale burial of macroalgal detritus in marine sediments: Effects of Ulva spp. on the spatial distribution of macrofauna assemblages. Journal of Experimental Marine Biology and Ecology 332, 84-95.

Sánchez-Carrillo, S., Sánchez-Andrés, R., Alatorre, L. C., Angeler, D. G., ÁlvarezCobelas, M., and Arreola-Lizárraga, J. A. (2009). Nutrient fluxes in a semi-arid microtidal mangrove wetland in the Gulf of California. Estuarine, Coastal and Shelf Science 82, 654-662.

Santos, I. R., Bryan, K. R., Pilditch, C. A., and Tait, D. R. (2014). Influence of porewater exchange on nutrient dynamics in two New Zealand estuarine intertidal flats. Marine Chemistry 167, 57-70. 
697 Santos, I. R., Eyre, B. D., and Huettel, M. (2012). The driving forces of porewater and groundwater flow in permeable coastal sediments: A review. Estuarine, Coastal and Shelf Science 98, 1-15.

Savage, C., Thrush, S. F., Lohrer, A. M., and Hewitt, J. E. (2012). Ecosystem services transcend boundaries: estuaries provide resource subsidies and influence functional diversity in coastal benthic communities. PloS ONE 7, e42708.

Silva, C. A. R., Mozeto, A. A., and Ovalle, Á. R. C. (1998). Distribution and fluxes as macrodetritus of phosphorus in red mangroves, Sepetiba Bay, Brazil. Mangroves and Salt Marshes 2, 37-42.

Sontek/YSI Inc., (2007). 'FlowTracker Handheld ADV technical manual, firmware version 3.3, software version 2.20.' (Sontek/YSI Inc.: San Diego, USA)

Thrush, S.F., Hewitt, J.E., Gibbs, M., Lundquist, C., Norkko, A. (2006). Functional role of large organisms in intertidal communities: Community effects and ecosystem function. Ecosystems 9, 1029-1040.

711 Turner, S. J. (2007). Growth and productivity of intertidal Zostera capricorni in New Zealand estuaries. New Zealand Journal of Marine and Freshwater Research 41, $77-90$.

714 Tyrrell, T. (1999). The relative influences of nitrogen and phosphorus on oceanic primary production. Nature 400, 525-531.

716 Underwood, G. J. C., and Kromkamp, J. C. (1999). Primary production by phytoplankton and microphytobenthos in estuaries. Advances in Ecological Research 29, 93-153. 
718 Valiela, I., Cole, M. L., McClelland, J., Hauxwell, J., and Cebrian, J. (2000). Role of salt marshes as part of coastal landscapes. In 'Concepts and controversies in tidal marsh ecology’. (Eds M. P. Weinstein and D. A. Kreeger) pp. 23-39. (Kluwer Academic Publishers: Dordecht)

722 Wattayakorn, G., Wolanski, E., and Kjerfve, B. (1990). Mixing, trapping and outwelling in the Klong Ngao mangrove swamp, Thailand. Estuarine, Coastal and Shelf Science 31, 667-688.

Woodroffe, C. D. (1985). Studies of a mangrove basin, Tuff Crater, New Zealand: III. The 726 flux of organic and inorganic particulate matter. Estuarine, Coastal and Shelf Science 20, 447-461.

728 
Figures:

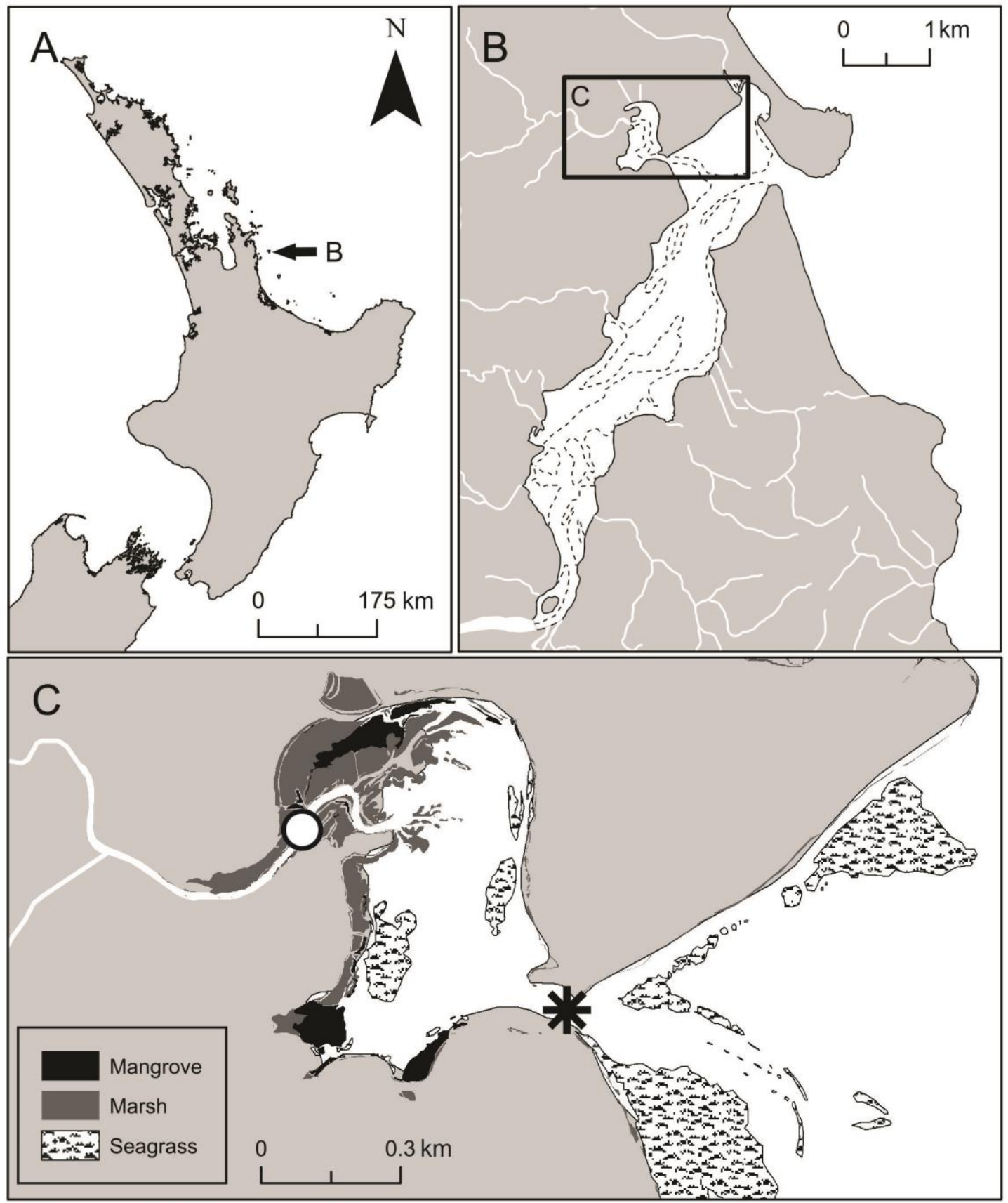

Fig. 1. Map of North Island, New Zealand (A), Tairua Estuary with the intertidal boundary shown by dashed lines (B), and Pepe Inlet showing the distribution of vegetated habitats (C). Water sampling for dissolved and particulate $\mathrm{N}$ and $\mathrm{P}$, and chlorophyll a was carried out at both ' $\bigcirc$ ' and '*', and sampling of macrodetritus only at '*'. Data source: Waikato Regional Council, Hamilton, New Zealand (GIS vegetation layers). 


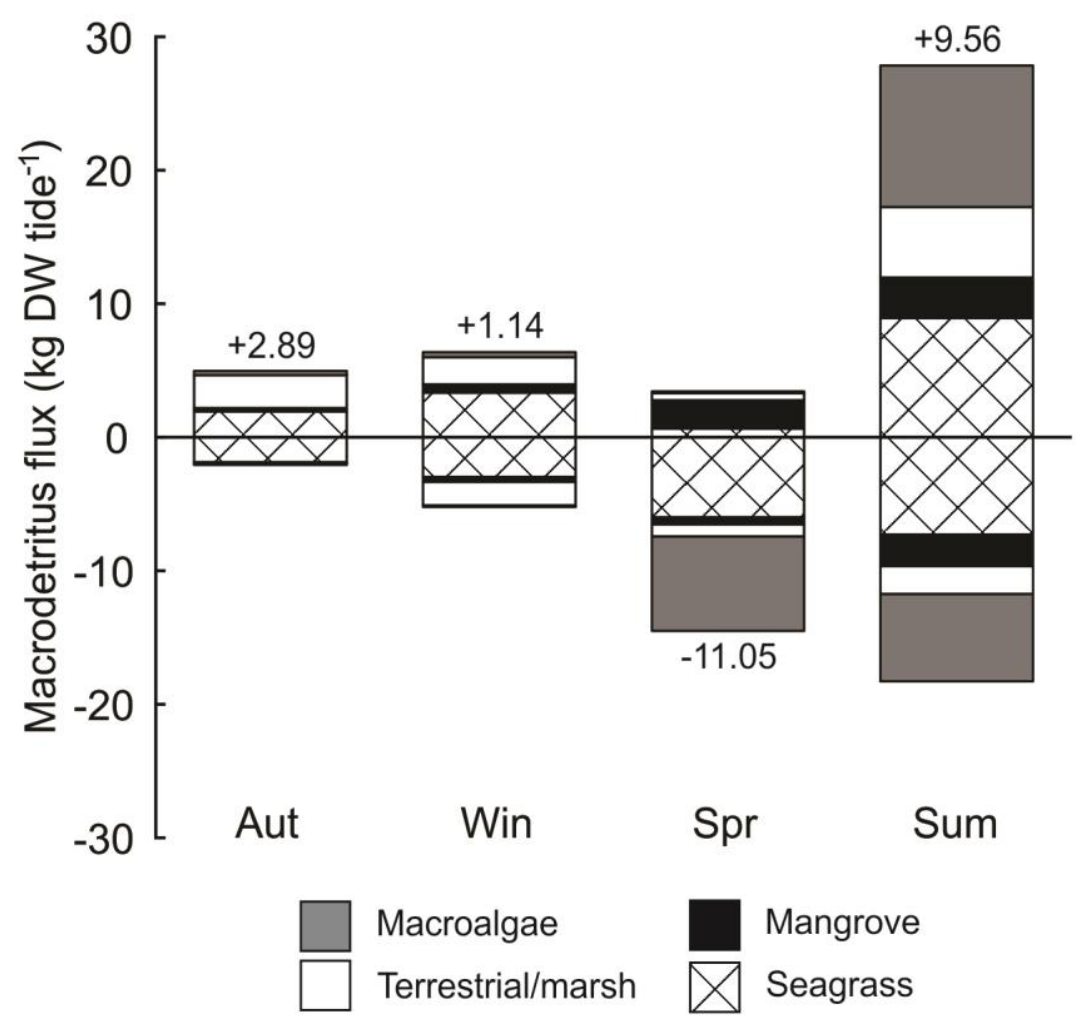

Fig. 2. Fluxes of macrodetritus from Pepe Inlet, Tairua Estuary, as a function of season $($ Aut $=$ Feb 2014, Win $=$ Jul 2014, Spr $=$ Nov 2014, Sum $=$ Feb 2015 $)$ and tidal direction (ebb tide fluxes are indicated by positive numbers, and flood tide fluxes are negative; fluxes are the mean of two flood or ebb tides). The net flux (ebb minus flood) is given above/below the bar (in kg DW tidal cycle ${ }^{-1}$ ) for each season, and fluxes are separated by source. 

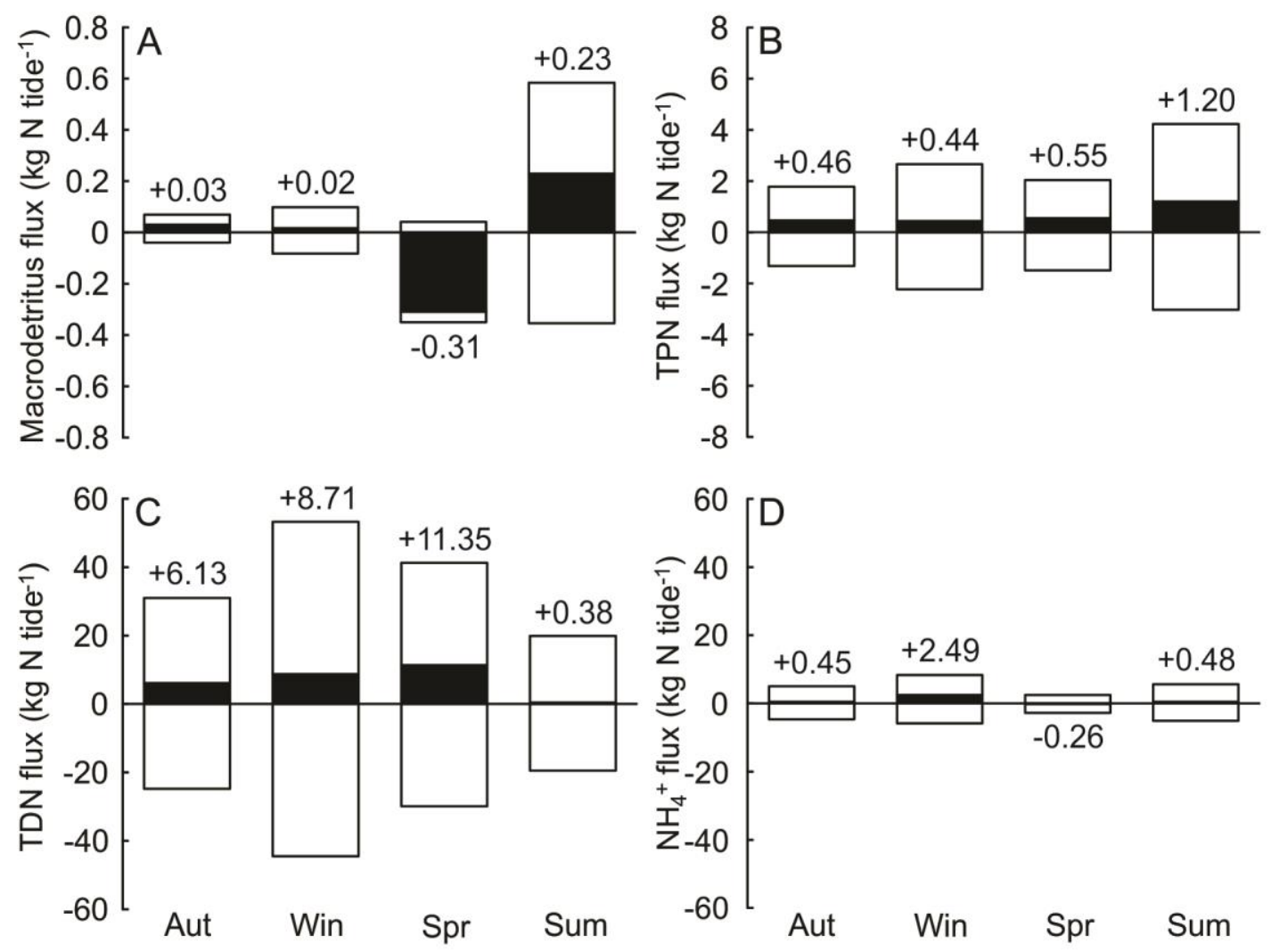

Fig. 3. Nitrogen flux as macrodetritus (A), particulate (TPN; B), and dissolved (TDN, C, and ammonium $\left.\mathrm{NH}_{4}{ }^{+}, \mathbf{D}\right)$, from Pepe Inlet, Tairua Estuary, as a function of season (Aut = Feb 2014, Win $=$ Jul 2014, Spr $=$ Nov 2014, Sum $=$ Feb 2015) and tidal direction (ebb tide fluxes are indicated by positive numbers, and flood tide fluxes are negative; fluxes are the mean of two flood or ebb tides). White bars indicate the total flux for each tide, and the net flux (ebb minus flood) is indicated with black bars and given as $\mathrm{kg} \mathrm{N}$ tidal cycle ${ }^{-1}$ below/above bars. The scale of the y-axes differ between sub-plots. 


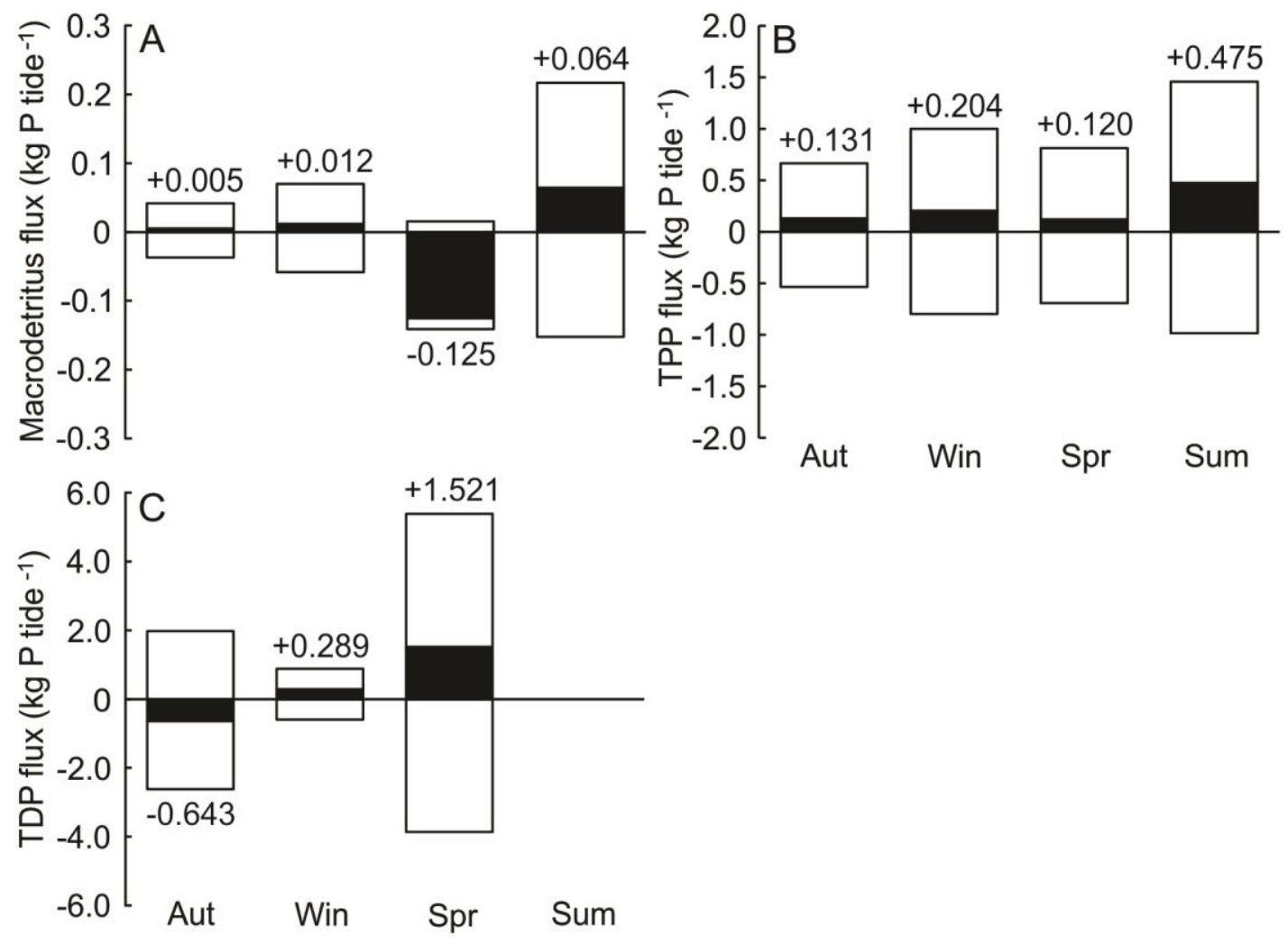

Fig. 4. Phosphorus flux as macrodetritus (A), particulate (TPP; B), and dissolved (TDP; C), from Pepe Inlet, Tairua Estuary, as a function of season (Aut = Feb 2014, Win = Jul 2014, Spr $=$ Nov 2014, Sum $=$ Feb 2015) and tidal direction (ebb tide fluxes are indicated by positive numbers, and flood tide fluxes are negative; fluxes are the mean of two flood or ebb tides). White bars indicate the total flux for each tide, and the net flux (ebb minus flood) is indicated with black bars and given as $\mathrm{kg} \mathrm{P}$ tidal cycle ${ }^{-1}$ below/above bars. In Sum, TDP was below detection limit. The scale of the y-axes differ between sub-plots. 


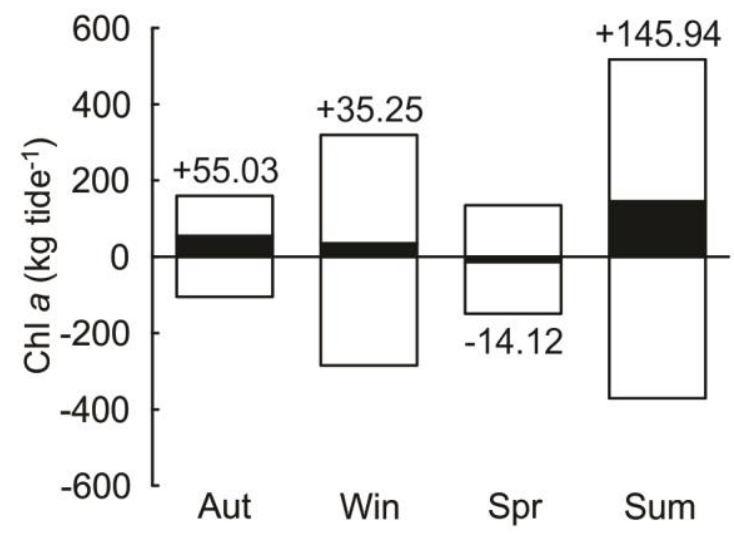

Fig. 5. Particulate chlorophyll $a(\mathrm{chl} a)$ flux from Pepe Inlet, Tairua Estuary, as a function of season (Aut $=$ Feb 2014, Win $=$ Jul 2014, Spr $=$ Nov 2014, Sum $=$ Feb 2015) and tidal direction (ebb tide fluxes are indicated by positive numbers, and flood tide fluxes are negative; fluxes are the mean of two flood or ebb tides). White bars indicate the total flux for each tide, and the net flux (ebb minus flood) is indicated with black bars and given in $\mathrm{kg}$ tidal cycle $\mathrm{e}^{-1}$ below/above bars. 


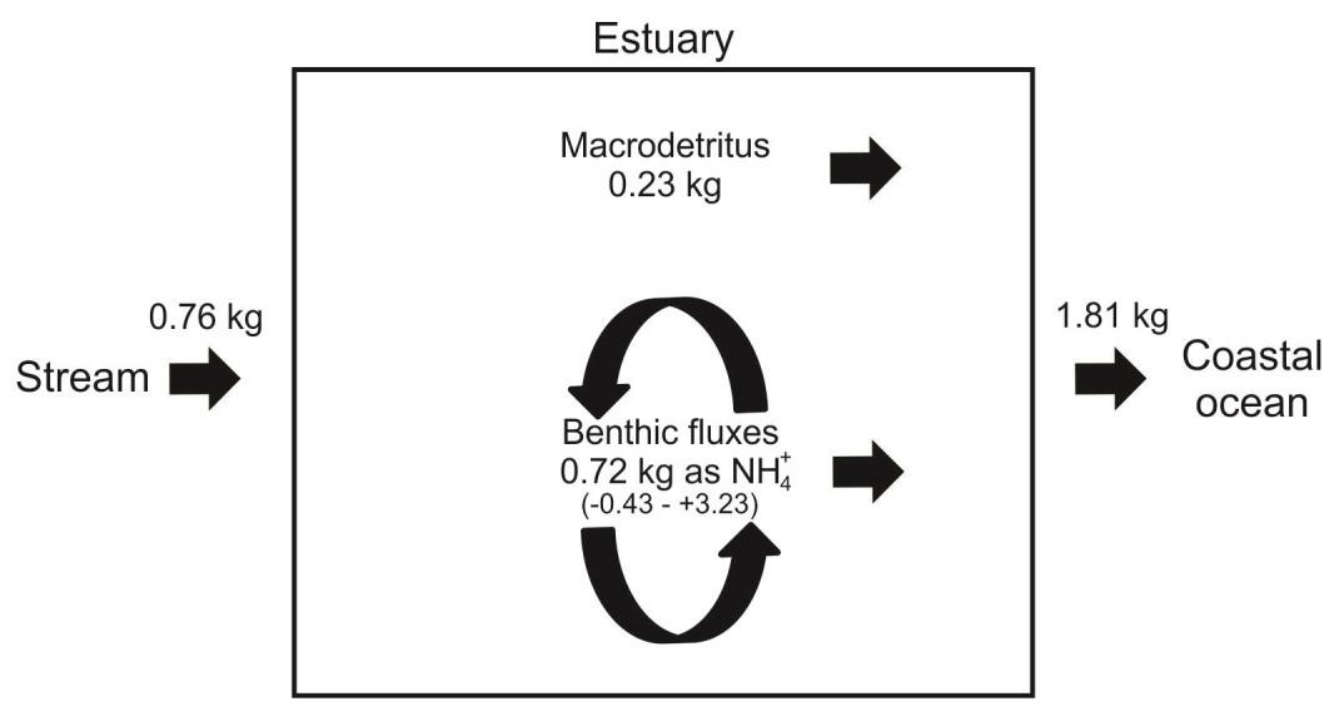

Fig. 6. Conceptual diagram of simplified total nitrogen fluxes (in $\mathrm{kg} \mathrm{N}$ tidal cycle ${ }^{-1}$ ) in summer, including inputs of total $\mathrm{N}$ from Pepe Stream, $\mathrm{N}$ as $\mathrm{NH}_{4}{ }^{+}$from the benthos, and total $\mathrm{N}$ exported at the mouth of Pepe Inlet. Benthic fluxes are the night and day average of those measured in Pepe Inlet in Gladstone-Gallagher et al. $(2017 ; \mathrm{n}=16$, with adult crab densities of 12-108 ind. $\left.\mathrm{m}^{-2}\right)$, and are scaled up to the estuary area $\left(259,909 \mathrm{~m}^{2}\right.$ calculated using analysis of aerial photographs), and approximate time that the majority of the intertidal flat area is covered by water ( $\sim \mathrm{h}$, personal observation) (range for benthic fluxes is shown in brackets; positive benthic fluxes indicate an efflux of $\mathrm{NH}_{4}{ }^{+}$out of the sediment and into the water column, and negative indicates uptake by the sediments). 
Tables:

Table 1. Input of dissolved nitrogen and phosphorus (TDN, TDP), ammonium $\left(\mathrm{NH}_{4}^{+}\right)$, particulate nitrogen and phosphorus (TPN, TPP), and chlorophyll a (chl $\left.a\right)$, from Pepe Stream into Pepe Inlet, as a function of season (Aut = Feb 2014, Win = Jul 2014, Spr $=$ Nov 2014, Sum $=$ Feb 2015)

Values are the mean of two tidal cycles, and given in brackets is the percentage contribution of the stream to the net exports from Pepe Inlet (a percentage is not given in the case of a net import into Pepe Inlet). The total N (TDN + TPN) and P (TDP + TPP) contributed by Pepe Stream are also given.

\begin{tabular}{|c|c|c|c|c|c|c|c|c|}
\hline Source & Aut & & Win & & Spr & & Sum & \\
\hline TDN (kg N tidal cycle $\left.{ }^{-1}\right)$ & 1.228 & $(20 \%)$ & 1.006 & $(12 \%)$ & 0.870 & $(8 \%)$ & 0.568 & $(149 \%)$ \\
\hline $\mathrm{NH}_{4}{ }^{+}\left(\mathrm{kg} \mathrm{N}\right.$ tidal cycle $\left.{ }^{-1}\right)$ & 0.248 & $(55 \%)$ & 0.155 & $(6 \%)$ & 0.218 & & 0.213 & $(44 \%)$ \\
\hline TDP (kg P tidal cycle $\left.{ }^{-1}\right)$ & 0.096 & & 0.037 & $(13 \%)$ & 0.068 & $(4 \%)$ & 0.041 & \\
\hline TPN (kg N tidal cycle $\left.{ }^{-1}\right)$ & O & $\left(30^{c}\right.$ & 0 . & $(1$ & 9 & 6) & 0.188 & $(16 \%)$ \\
\hline TPP $\left(\mathrm{kg} \mathrm{N}\right.$ tidal cycle $\left.{ }^{-1}\right)$ & 0.042 & $(32 \%)$ & 0.028 & $(14 \%)$ & 0.090 & $(74 \%)$ & 0.050 & $(10 \%)$ \\
\hline Chl $a\left(\right.$ kg tidal cycle $\left.^{-1}\right)$ & 30.210 & $(55 \%)$ & 3.609 & $(10 \%)$ & 90.727 & & 43.957 & $(30 \%)$ \\
\hline Total N (kg N tidal cycle $\left.{ }^{-1}\right)$ & 1.364 & $(21 \%)$ & 1.090 & $(12 \%)$ & 1.149 & $(10 \%)$ & 0.756 & $(42 \%)$ \\
\hline Total P (kg P tidal cycle $\left.{ }^{-1}\right)$ & 0.136 & & 0.065 & $(13 \%)$ & 0.158 & $(10 \%)$ & 0.091 & $(19 \%)$ \\
\hline
\end{tabular}


Table 2. Nitrogen (N) budget model for Pepe Inlet across seasons (Aut = Feb 2014, Win $=$ Jul 2014, Spr = Nov 2014, Sum = Feb 2015)

Values are in $\mathrm{kg} \mathrm{N}$ tidal cycle ${ }^{-1}$. $\mathrm{N}$ supplied to the water column from the benthos for Pepe Inlet are the night and day average of those measured in Pepe Inlet (Gladstone-Gallagher et al. $2017 ; \mathrm{n}=16$, with adult crab densities of $12-108$ ind. $\mathrm{m}^{-2}$ ), and benthic fluxes from Pratt et al.(2014) are measured in nine estuaries across a comprehensive seasonal range (n $=143$; the maximum and minimum values reported here represent the average of values above the 90th percentile and below the 10th percentile). $\mathrm{NH}_{4}{ }^{+}$fluxes (from GladstoneGallagher et al. 2017 and Pratt et al. 2014) are scaled up to the estuary area $\left(259,909 \mathrm{~m}^{2}\right.$ calculated using analysis of aerial photographs), and approximate time that the majority of the intertidal flat area is covered by water ( $\sim 6 \mathrm{~h}$, personal observation) (positive benthic fluxes indicate an efflux of $\mathrm{NH}_{4}{ }^{+}$out of the sediment and into the water column, and negative indicates uptake by the sediments).

\begin{tabular}{|c|c|c|c|c|c|c|c|}
\hline \multirow[b]{2}{*}{ Season } & \multirow[b]{2}{*}{ Stream } & \multirow[b]{2}{*}{$\begin{array}{l}\text { Macro- } \\
\text { detritus }\end{array}$} & \multirow[b]{2}{*}{$\begin{array}{l}\text { Total } \\
\text { export }\end{array}$} & \multirow[b]{2}{*}{$\begin{array}{l}\text { Unaccounted } \\
\mathbf{N}\end{array}$} & \multicolumn{2}{|c|}{$\mathrm{NH}_{4}{ }^{+}$from benthos } & \multirow{2}{*}{$\begin{array}{l}\mathrm{N} \text { unaccounted } \\
\text { for using range } \\
\text { of benthic fluxes } \\
\text { from Pratt } \text { et al. } \\
(2014)\end{array}$} \\
\hline & & & & & $\begin{array}{l}\text { Pepe Inlet: } \\
\text { Gladstone- } \\
\text { Gallagher } \\
\text { et al. }(2017)\end{array}$ & $\begin{array}{l}\text { Pratt et al. } \\
(2014)\end{array}$ & \\
\hline Aut & 1.36 & 0.03 & 6.62 & 5.23 & Mean 0.72 & Mean 1.23 & 0.46 \\
\hline Win & 1.09 & 0.02 & 9.17 & 8.06 & Min -0.43 & Min -0.19 & 3.29 \\
\hline Spr & 1.15 & -0.31 & 11.59 & 10.44 & $\operatorname{Max} 3.23$ & $\operatorname{Max} 4.77$ & 5.67 \\
\hline Sum & 0.76 & 0.23 & 1.81 & 0.82 & & & 0 \\
\hline
\end{tabular}




\section{Appendices:}

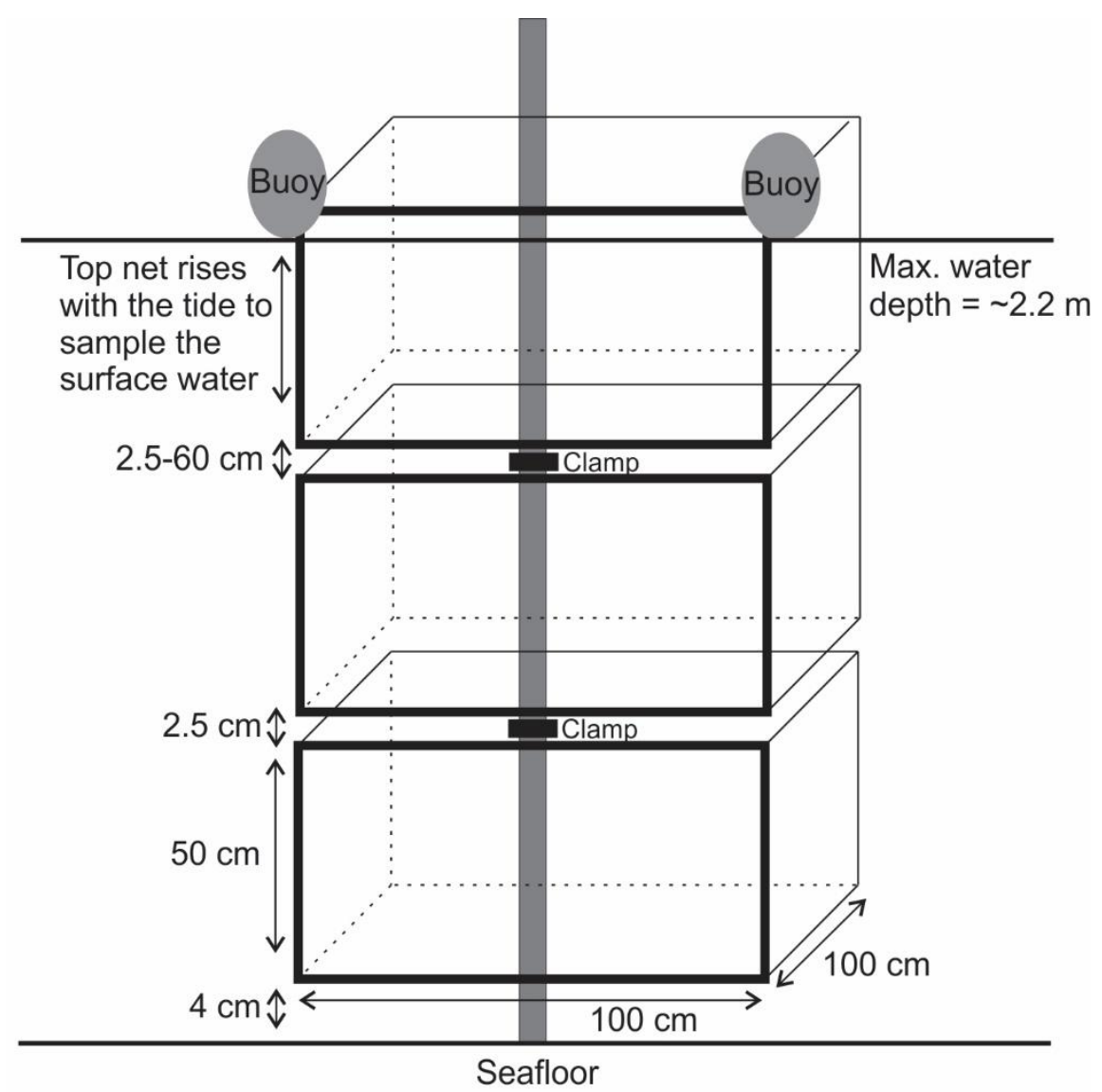

Fig. A1. Diagram of one of the two sets of macrodetritus nets positioned in the main channel at the mouth of Pepe Inlet, Tairua Estuary (diagram is not to scale). 

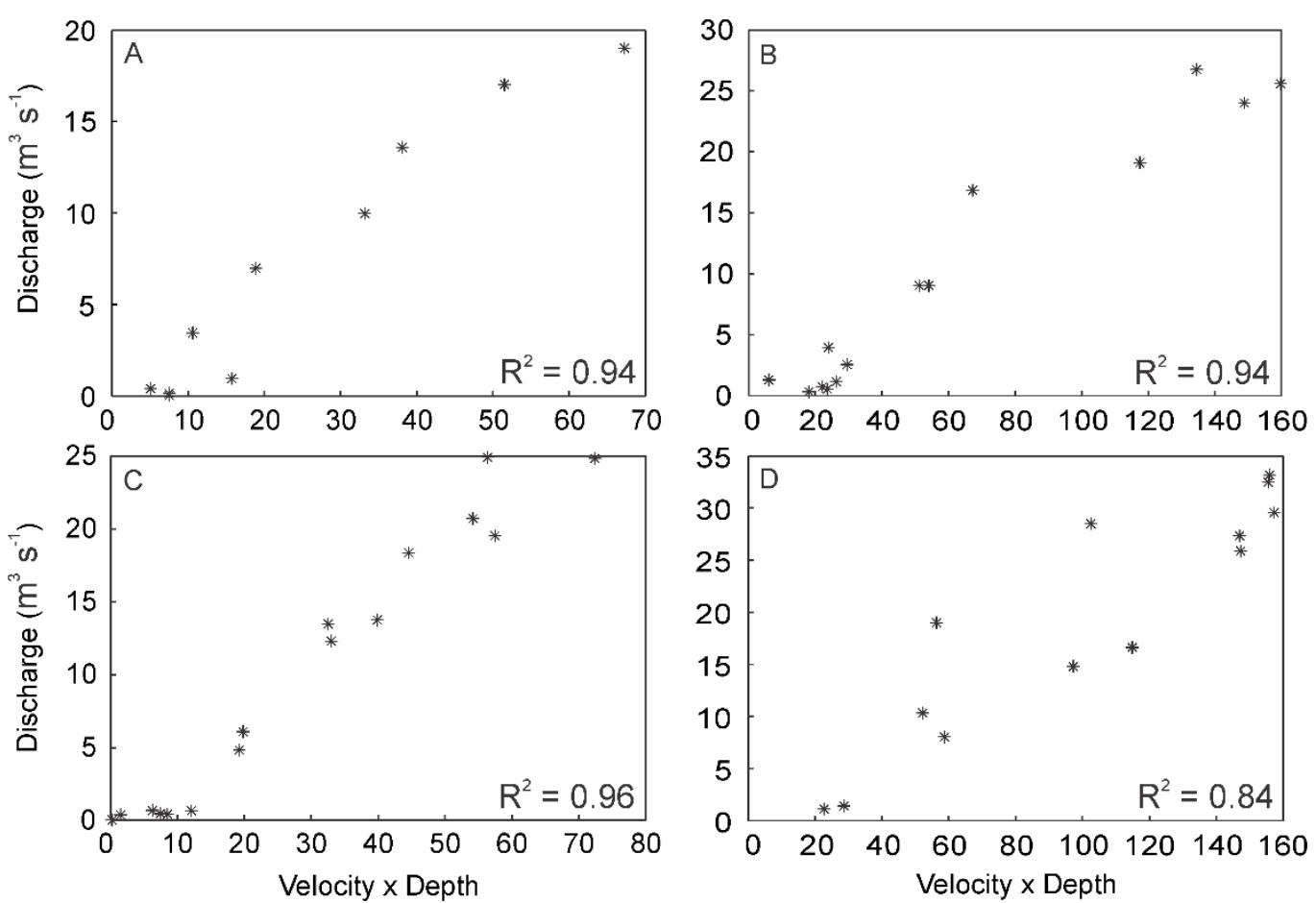

Fig. A2. Correlations used to predict discharge, between velocity $\times$ depth $($ ADV/ADCP measurement interval $=10 \mathrm{~min})$ and discrete discharge measurements (Flowtracker ADV) on each sampling date (A = May 2014 - Aut, B = Jul 2014 - Win, C = Nov $2014-$ Spr, D = Feb 2015 - Sum). 

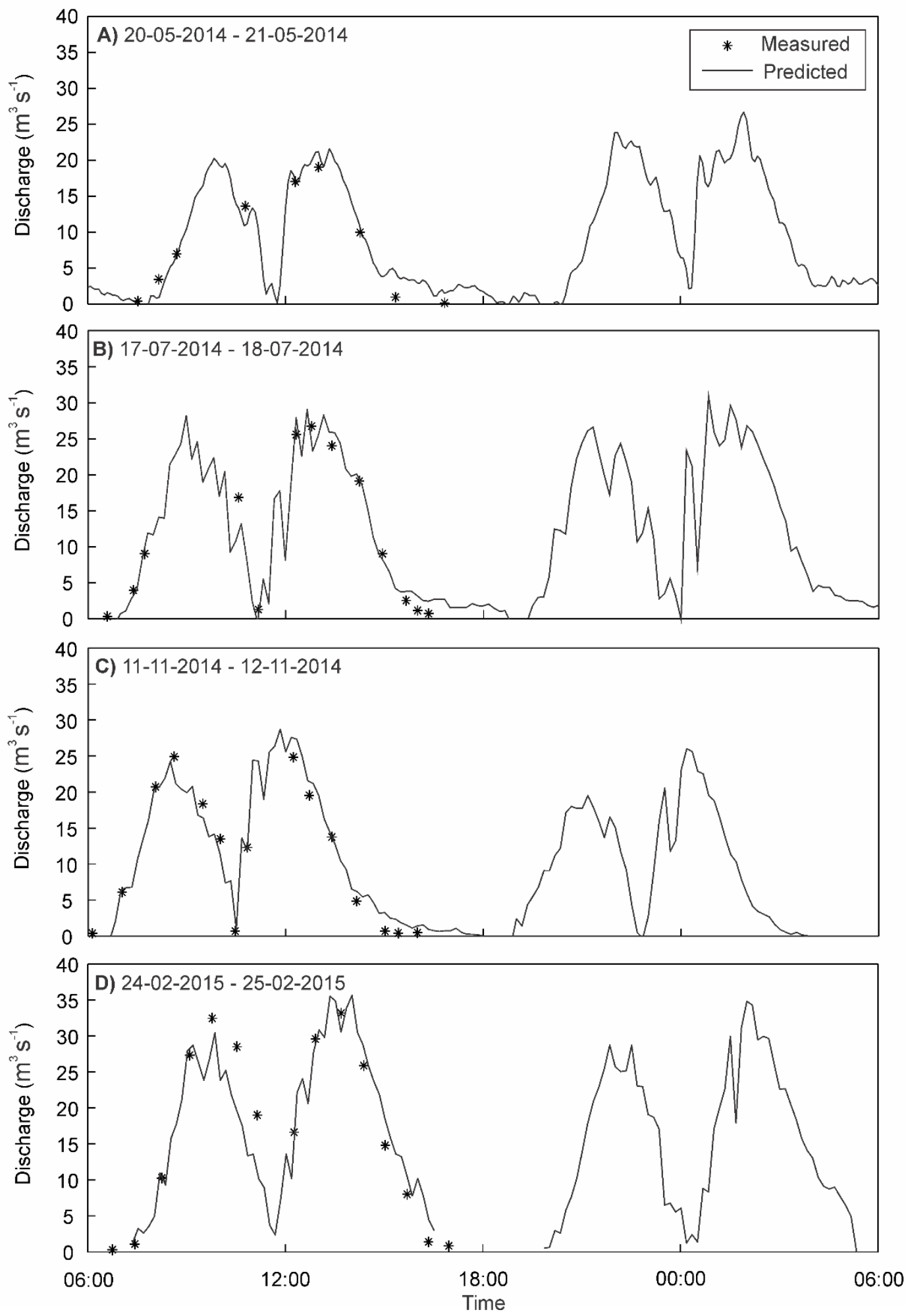

Fig. A3. Predicted and measured discharge as a function of time, on each sampling date (A = May $2014-$ Aut, $\mathbf{B}=$ Jul $2014-$ Win, C = Nov $2014-$ Spr, D = Feb $2015-$ Sum).

Discharge is predicted using a correlation between velocity $\times$ depth (ADV/ADCP 
measurement interval $=10 \mathrm{~min}$ ), and discrete discharge measurements in the first half of the tidal cycle (using Flowtracker ADV; i.e. measured; see Figure A1 for correlations). 
Table A1. Summary of estuary-to-coast macrodetritus flux studies.

Only studies that infer direction (i.e. import or export) of macrodetritus fluxes, across a semi-enclosed estuary or bay to open coast boundary are included in the summary. Fluxes of other forms of production (dissolved and particulates) are only included when they were measured simultaneously with macrodetritus fluxes. The source of the data is given as superscripted numbers in the 'location' column that correspond to references listed in the table footnotes. Abbreviations are defined in the table footnotes. 


\begin{tabular}{|c|c|c|c|c|c|c|c|c|}
\hline Location & Estuary description & $\begin{array}{l}\text { Location of } \\
\text { measurements }\end{array}$ & Estuary area & Form & $\begin{array}{l}\text { Season/ } \\
\text { Annual } \\
\text { estimate }\end{array}$ & Position & Direction & Fluxes \\
\hline \multirow{9}{*}{$\begin{array}{l}\text { North Inlet } \\
\text { South Carolina } \\
\text { USA }\left(33^{\circ} \mathrm{N}\right)^{1-3}\end{array}$} & \multirow{9}{*}{$\begin{array}{l}\text { Bar-built estuary } \\
\text { Ebb-dominated } \\
\text { Small freshwater input } \\
\text { Tidal flushing }=55 \% \\
\text { water replaced per tide } \\
\text { Spr tidal range }=2.2 \mathrm{~m} \\
\text { Mean tidal range }=1.6 \mathrm{~m} \\
3 \text { major tidal creeks } \\
\text { Current velocities }=\text { max. } \\
2.3 \mathrm{~m} \mathrm{~s}^{-1}\end{array}$} & \multirow{9}{*}{$\begin{array}{l}\text { In the } 3 \text { main } \\
\text { tidal channels } \\
\text { (up to } 180 \mathrm{~m} \\
\text { each) }\end{array}$} & \multirow{9}{*}{$\begin{array}{l}3200 \text { ha } \\
21 \% \text { tidal creeks } \\
73 \% \text { saltmarsh } \\
5 \% \text { mudflats } \\
1 \% \text { oyster reef }\end{array}$} & \multirow[t]{4}{*}{$\mathrm{Md}$} & \multirow{4}{*}{ Annual } & \multirow{4}{*}{$\mathrm{S}(60 \mathrm{~cm})$} & \multirow[t]{4}{*}{$\mathrm{E}$} & $63257 \mathrm{~kg} \mathrm{DW}$ \\
\hline & & & & & & & & $21000 \mathrm{~kg} \mathrm{C}$ \\
\hline & & & & & & & & $240 \mathrm{~kg} \mathrm{~N}$ \\
\hline & & & & & & & & $24 \mathrm{~kg} \mathrm{P}$ \\
\hline & & & & Par & & S,M,B & $\mathrm{E}$ & $3000000 \mathrm{~kg} \mathrm{C}$ (as POC) \\
\hline & & & & \multirow[t]{4}{*}{ Dis } & & \multirow[t]{4}{*}{ S,M,B } & \multirow[t]{4}{*}{$\mathrm{E}$} & $7800000 \mathrm{~kg} \mathrm{C}$ (as DOC) \\
\hline & & & & & & & & $171000 \mathrm{~kg} \mathrm{~N}\left(\right.$ as $\left.\mathrm{NH}_{4}{ }^{+}+\mathrm{NO}_{\mathrm{x}}\right)$ \\
\hline & & & & & & & & $40000 \mathrm{~kg} \mathrm{P}\left(\right.$ as $\left.\mathrm{PO}_{4}\right)$ \\
\hline & & & & & & & & \\
\hline \multirow{6}{*}{$\begin{array}{l}\text { Tuff Crater } \\
\text { Auckland } \\
\text { New Zealand } \\
\left(36^{\circ} \mathrm{S}\right)^{4}\end{array}$} & \multirow{6}{*}{$\begin{array}{l}\text { Mangrove basin } \\
\text { Tidally drained by breach } \\
\text { in the crater wall } \\
\text { Minimal freshwater input } \\
\text { Spr tidal range }=2.69 \mathrm{~m} \\
\text { Neap tidal range }=1.99 \mathrm{~m} \\
\text { (in Waitemata Harbour, } \\
\text { but the ranges in the crater } \\
\text { are much less) }\end{array}$} & \multirow{6}{*}{$\begin{array}{l}\text { In the single } \\
\text { tidal creek }\end{array}$} & \multirow{6}{*}{$\begin{array}{l}21.6 \text { ha } \\
\text { entirely } \\
\text { mangroves }\end{array}$} & \multirow[t]{6}{*}{$\mathrm{Md}$} & Nov & \multirow[t]{6}{*}{$\mathrm{S}(50 \mathrm{~cm})$} & \multirow[t]{6}{*}{$\mathrm{E}$} & $0.035-0.036 \mathrm{~kg}$ DW tidal cycle $\mathrm{c}^{-1}$ \\
\hline & & & & & Dec & & & $0.3-1.5 \mathrm{~kg}$ DW tidal cycle $\mathrm{e}^{-1}$ \\
\hline & & & & & Annual & & & $162-915 \mathrm{~kg}$ DW \\
\hline & & & & & & & & \\
\hline & & & & & & & & \\
\hline & & & & & & & & \\
\hline \multirow{7}{*}{$\begin{array}{l}\text { Klong Ngao } \\
\text { Estuary, } \\
\text { Thailand }\left(9^{\circ} \mathrm{N}\right)^{5}\end{array}$} & \multirow{7}{*}{$\begin{array}{l}\text { Mangrove swamp drained } \\
\text { from a single tidal } \\
\text { channel } \\
\text { Annual rainfall }=4 \mathrm{~m} \\
\text { Rains for } 190 \mathrm{~d} \text { per year } \\
\text { Spr tidal range }=4.4 \mathrm{~m} \\
\text { Mean tidal range }=2.4 \mathrm{~m} \\
\text { Mangroves are only } \\
\text { totally submerged } 1-2 \\
\text { times per month }\end{array}$} & \multirow{7}{*}{$\begin{array}{l}\text { In mouth of } \\
\text { Tidal channel } \\
\text { (47 m width) }\end{array}$} & \multirow{7}{*}{$\begin{array}{l}1150 \text { ha } \\
\text { almost entirely } \\
\text { mangroves }\end{array}$} & $\mathrm{Md}$ & Annual & $\mathrm{S}$ & $\mathrm{E}$ & $0.06-0.25 \mathrm{~kg} \mathrm{DW} \mathrm{ha}^{-1}$ day $^{-1}$ \\
\hline & & & & \multirow[t]{6}{*}{ Dis } & $\begin{array}{l}\text { Dry } \\
\text { season }\end{array}$ & & $\mathrm{E}$ & $\begin{array}{l}26 \mathrm{~kg} \mathrm{~N} \text { day }^{-1}\left(\text { as } \mathrm{NO}_{\mathrm{x}} \text { ) }\right. \\
\text { (other forms of } \mathrm{N}, \mathrm{P} \text { and } \mathrm{C} \text { were } \\
\text { not measured during the dry } \\
\text { season) }\end{array}$ \\
\hline & & & & & \multirow{5}{*}{$\begin{array}{l}\text { Wet } \\
\text { season }\end{array}$} & & \multirow[t]{5}{*}{$\mathrm{E}$} & $15 \mathrm{~kg} \mathrm{~N} \mathrm{day}^{-1}(\mathrm{TDN})$ \\
\hline & & & & & & & & (of which $4 \mathrm{~kg} \mathrm{~N}$ ayy $^{-1}$ as $\mathrm{NO}_{\mathrm{x}}$ ) \\
\hline & & & & & & & & $13 \mathrm{~kg} \mathrm{P} \mathrm{day}^{-1}$ (TDP) \\
\hline & & & & & & & & (of which $0.2 \mathrm{~kg} \mathrm{P} d a y^{-1}$ as $\mathrm{PO}_{4}$ ) \\
\hline & & & & & & & & $\begin{array}{l}5600 \mathrm{~kg} \mathrm{C} \mathrm{day}^{-1} \text { (TOC incl. Dis } \\
\text { and Par) }\end{array}$ \\
\hline
\end{tabular}


Table A1 continued.

\begin{tabular}{|c|c|c|c|c|c|c|c|c|}
\hline Location & Estuary description & $\begin{array}{l}\text { Location of } \\
\text { measurements }\end{array}$ & Estuary area & Form & $\begin{array}{l}\text { Season/ } \\
\text { Annual } \\
\text { estimate }\end{array}$ & Position & Direction & Fluxes \\
\hline $\begin{array}{l}\text { Sepetiba Bay } \\
\text { Brazil } \\
\left(23^{\circ} \mathrm{S}\right) \\
\text { Silva et al. } \\
1993 \text { as cited } \\
\text { in } 6,7\end{array}$ & $\begin{array}{l}\text { Mangrove-dominated bay } \\
\text { enclosed by two tidal } \\
\text { creeks } \\
\text { Peak tidal range }=2.0 \mathrm{~m} \\
\text { Freshwater input minimal }\end{array}$ & Not reported & 4 ha mangroves & $\mathrm{Md}$ & Annual & Not reported & $\mathrm{E}$ & $420 \mathrm{~kg} \mathrm{DW} \mathrm{ha-1}$ \\
\hline $\begin{array}{l}\text { Saeftinge marsh } \\
\text { Westerschelde } \\
\text { Estuary } \\
\text { Netherlands } \\
\left(51^{\circ} \mathrm{N}\right)^{8}\end{array}$ & $\begin{array}{l}\text { Tidal marsh with many } \\
\text { tidal creeks } \\
\text { Upper marsh is relatively } \\
\text { closed to the tide (above } \\
\text { mean neap tide level) }\end{array}$ & $\begin{array}{l}\text { In one of the } \\
\text { many tidal } \\
\text { creeks ( } 36 \mathrm{~m} \\
\text { width) }\end{array}$ & $\begin{array}{l}2800 \text { ha } \\
\text { saltmarsh }\end{array}$ & $\mathrm{Md}$ & Annual & $\mathrm{B}$ & $\mathrm{E}$ & $550 \mathrm{~kg} \mathrm{DW}$ \\
\hline $\begin{array}{l}\text { Mont Saint- } \\
\text { Michel Bay } \\
\text { Brittany } \\
\text { France }\left(48^{\circ} \mathrm{N}\right)^{9}\end{array}$ & $\begin{array}{l}\text { Macro-tidal estuary } \\
\text { Mean tidal range }=12 \mathrm{~m} \\
\text { Spr tidal range }=16 \mathrm{~m} \\
\text { Marsh infrequently } \\
\text { inundated ( }<16 \% \text { of tides })\end{array}$ & $\begin{array}{l}\text { In one channel } \\
\text { draining } 5 \text { ha } \\
\text { watershed } \\
\text { ( } 3 \text { m width })\end{array}$ & $\begin{array}{l}19000 \text { ha mudflat } \\
4000 \text { ha saltmarsh }\end{array}$ & $\mathrm{Md}$ & Annual & $\mathrm{S}(40 \mathrm{~cm})$ & $\mathrm{E}$ & $\begin{array}{l}33 \mathrm{~kg} \mathrm{DW} \\
14 \mathrm{~kg} \mathrm{C} \\
0.5 \mathrm{~kg} \mathrm{~N}\end{array}$ \\
\hline 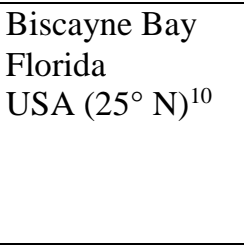 & $\begin{array}{l}\text { Coastal cut separated } \\
\text { from the open ocean by } \\
\text { Islands (open system) } \\
\text { Current velocities = } \\
0.5-0.7 \mathrm{~m} \mathrm{~s}^{-1} \text { through the } \\
\text { inlet }\end{array}$ & $\begin{array}{l}\text { Entrance of } \\
\text { several coastal } \\
\text { cuts }\end{array}$ & NA & $\mathrm{Md}$ & $\begin{array}{l}\text { Aug } \\
\text { Dec } \\
\text { May }\end{array}$ & WC & $\begin{array}{l}\text { I } \\
\text { I } \\
\text { I }\end{array}$ & $\begin{array}{l}109 \mathrm{~kg} \mathrm{DW} \text { tidal cycle }{ }^{-1} \\
104 \mathrm{~kg} \text { DW tidal cycle }{ }^{-1} \\
424 \mathrm{~kg} \text { DW tidal cycle }{ }^{-1} \\
\text { (measured macroalgae fluxes } \\
\text { only) }\end{array}$ \\
\hline
\end{tabular}


Table A1 continued.

\begin{tabular}{|c|c|c|c|c|c|c|c|c|}
\hline Location & Estuary description & $\begin{array}{l}\text { Location of } \\
\text { measurements }\end{array}$ & Estuary area & Form & $\begin{array}{l}\text { Season/ } \\
\text { Annual } \\
\text { estimate }\end{array}$ & Position & Direction & Fluxes \\
\hline \multirow{3}{*}{$\begin{array}{l}\text { Mngazana } \\
\text { Estuary, South } \\
\text { Africa }\left(31^{\circ} \mathrm{S}\right)^{11}\end{array}$} & \multirow{3}{*}{$\begin{array}{l}\text { Mangrove dominated } \\
\text { Estuary, drains to the } \\
\text { open ocean through a } \\
\text { single mouth } \\
\text { River dominated }\end{array}$} & \multirow{3}{*}{$\begin{array}{l}\text { In mouth of } \\
\text { tidal channel }\end{array}$} & \multirow{3}{*}{118 ha mangrove } & \multirow[t]{2}{*}{$\mathrm{Md}$} & Nov & \multirow[t]{2}{*}{$\mathrm{S}(25 \mathrm{~cm})$} & $\mathrm{E}$ & $1.5 \mathrm{~kg} \mathrm{DW} \mathrm{day}^{-1}$ \\
\hline & & & & & June & & $\mathrm{E}$ & $0.4 \mathrm{~kg}^{\mathrm{DW}}$ day $^{-1}$ \\
\hline & & & & Par & Annual & $S$ & $\mathrm{E}$ & $36000 \mathrm{~kg} \mathrm{C} \mathrm{ha}^{-1}$ (as POC) \\
\hline Pepe Inlet & Barrier enclosed estuary & In the single & $\sim 26$ ha & Md & May (Aut) & WC & $\mathrm{E}$ & $2.89 \mathrm{~kg} \mathrm{DW}$ tidal cycle ${ }^{-1}$ \\
\hline Tairua Estuary & Ebb-dominated & tidal channel & Includes: & & & & $\mathrm{E}$ & $0.03 \mathrm{~kg} \mathrm{~N}$ tidal cycle ${ }^{-1}$ \\
\hline \multirow{23}{*}{$\begin{array}{l}\text { New Zealand } \\
\left(37^{\circ} \mathrm{S}\right)^{12}\end{array}$} & Tidal flushing $=82 \%$ & (37 m width) & $\sim 10$ ha saltmarsh & & & & $\mathrm{E}$ & $0.005 \mathrm{~kg}$ P tidal cycle ${ }^{-1}$ \\
\hline & water replaced per tide & & (some above high & & \multirow{3}{*}{\multicolumn{2}{|c|}{ Jul (Win) }} & $\mathrm{E}$ & $1.14 \mathrm{~kg} \mathrm{DW}$ tidal cycle ${ }^{-1}$ \\
\hline & Spr tidal range $=1.63 \mathrm{~m}$ & & tide) & & & & $\mathrm{E}$ & $0.02 \mathrm{~kg} \mathrm{~N}$ tidal cycle ${ }^{-1}$ \\
\hline & Neap tidal range $=1.22 \mathrm{~m}$ & & $\sim 2$ ha seagrass & & & & $\mathrm{E}$ & $0.011 \mathrm{~kg} \mathrm{P}$ tidal cycle ${ }^{-1}$ \\
\hline & Freshwater input from & & $\sim 3$ ha mangroves & & \multirow{3}{*}{\multicolumn{2}{|c|}{ Nov (Spr) }} & I & $11.05 \mathrm{~kg} \mathrm{DW}$ tidal cycle ${ }^{-1}$ \\
\hline & Pepe stream & & $\sim 20$ ha sandflat & & & & I & $0.31 \mathrm{~kg} \mathrm{~N}$ tidal cycle ${ }^{-1}$ \\
\hline & & & & & & & I & $0.125 \mathrm{~kg} \mathrm{P}$ tidal cycle ${ }^{-1}$ \\
\hline & & & & & \multirow{3}{*}{\multicolumn{2}{|c|}{ Feb (Sum) }} & $\mathrm{E}$ & $9.56 \mathrm{~kg}$ DW tidal cycle ${ }^{-1}$ \\
\hline & & & & & & & $\mathrm{E}$ & $0.23 \mathrm{~kg} \mathrm{~N}$ tidal cycle ${ }^{-1}$ \\
\hline & & & & & & & $\mathrm{E}$ & $0.064 \mathrm{~kg} P$ tidal cycle $^{-1}$ \\
\hline & & & & & \multirow{3}{*}{\multicolumn{2}{|c|}{ Annual }} & $\mathrm{E}$ & $449 \mathrm{~kg}$ DW \\
\hline & & & & & & & I & $6 \mathrm{~kg} \mathrm{~N}$ \\
\hline & & & & & & & $\mathrm{I}$ & $8 \mathrm{~kg} \mathrm{P}$ \\
\hline & & & & \multirow[t]{10}{*}{ Par } & \multirow[t]{2}{*}{ May (Aut) } & \multirow[t]{10}{*}{$S$} & $\mathrm{E}$ & $0.46 \mathrm{~kg} \mathrm{~N}$ tidal cycle c $^{-1}$ \\
\hline & & & & & & & $\mathrm{E}$ & $0.13 \mathrm{~kg}$ P tidal cycle ${ }^{-1}$ \\
\hline & & & & & \multirow[t]{2}{*}{ Jul (Win) } & & $\mathrm{E}$ & $0.44 \mathrm{~kg} \mathrm{~N}$ tidal cycle ${ }^{-1}$ \\
\hline & & & & & & & $\mathrm{E}$ & $0.20 \mathrm{~kg} P$ tidal cycle $^{-1}$ \\
\hline & & & & & \multirow[t]{2}{*}{ Nov (Spr) } & & $\mathrm{E}$ & $0.55 \mathrm{~kg} \mathrm{~N}$ tidal cycle ${ }^{-1}$ \\
\hline & & & & & & & $\mathrm{E}$ & $0.12 \mathrm{~kg} P$ tidal cycle $^{-1}$ \\
\hline & & & & & \multirow[t]{2}{*}{ Feb (Sum) } & & $\mathrm{E}$ & $1.20 \mathrm{~kg} \mathrm{~N}$ tidal cycle ${ }^{-1}$ \\
\hline & & & & & & & $\mathrm{E}$ & $0.47 \mathrm{~kg}$ P tidal cycle $^{-1}$ \\
\hline & & & & & \multirow[t]{2}{*}{ Annual } & & $\mathrm{E}$ & $467 \mathrm{~kg} \mathrm{~N}$ \\
\hline & & & & & & & $\mathrm{E}$ & $164 \mathrm{~kg} \mathrm{P}$ \\
\hline
\end{tabular}


Table A1 continued.

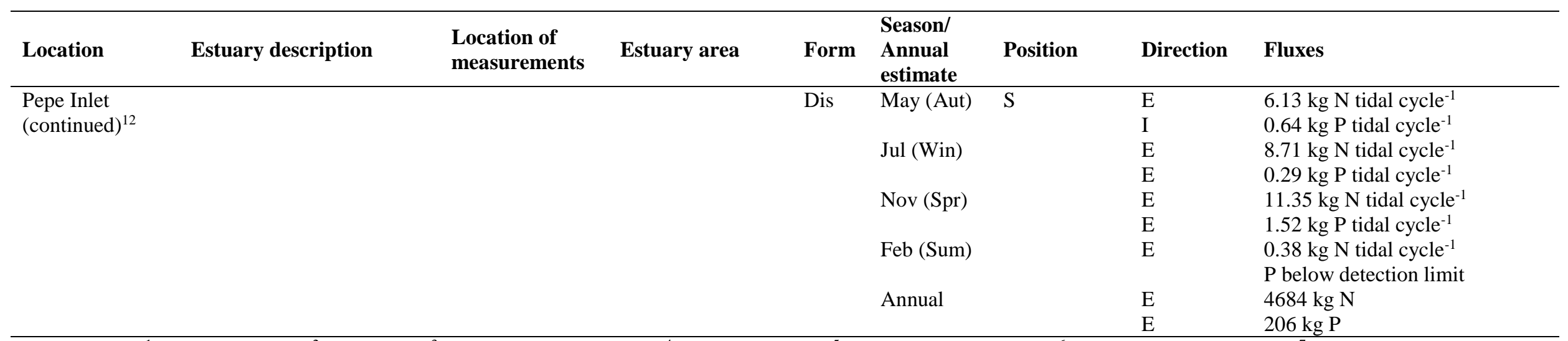

Data source: ${ }^{1}$ Dame et al. 1986; ${ }^{2}$ Dame $1982 ;{ }^{3}$ Dame and Stillwell 1984; ${ }^{4}$ Woodroffe $1985 ;{ }^{5}$ Wattayakorn et al. $1990 ;{ }^{6}$ Ramos e Silva et al. $2007 ;{ }^{7}$ Silva et al. 1998 ;

${ }^{8}$ Hemminga et al. $1996 ;{ }^{9}$ Bouchard and Lefeuvre 2000; ${ }^{10}$ Biber 2007; ${ }^{11}$ Rajkaran and Adams 2007; ${ }^{12}$ Current study; Form: Md = macrodetritus, Par = particulates, Dis =

dissolved; Direction: $\mathrm{E}=$ export, $\mathrm{I}=$ import; Position: $\mathrm{S}=$ surface waters, $\mathrm{M}=$ mid-water column, $\mathrm{B}=$ bottom, WC $=$ whole water column; Fluxes: scale of fluxes (e.g. annual

vs. daily or tidal cycle ${ }^{-1}$; or whole estuary vs ha ${ }^{-1}$ ) are given as they appear in the publications; $\mathrm{DW}=$ dry weight; $\mathrm{C}=$ carbon; $\mathrm{P}=$ phosphorus; $\mathrm{N}=$ nitrogen; In the current

study $^{13}$, annual fluxes are estimated by multiplying the average of the seasonal fluxes by the number of tidal cycles in one year (705 tidal cycles in Tairua Estuary in 2014 ) 
Table A2. Total calculated discharge (used in flux calculations) as a function of sampling date and tidal stage.

\begin{tabular}{ll}
\hline Sampling date & Total discharge $\left(\mathbf{m}^{\mathbf{3}}\right)$ \\
\hline May 2014 (Aut): & \\
Flood 1 & 146030 \\
Ebb 1 & 202860 \\
Flood 2 & 188820 \\
Ebb 2 & 230140 \\
Jul 2014 (Win): & \\
Flood 1 & 213490 \\
Ebb 1 & 288120 \\
Flood 2 & 228060 \\
Ebb 2 & 298270 \\
Nov 2014 (Spr): & \\
Flood 1 & 191160 \\
Ebb 1 & 271240 \\
Flood 2 & 153050 \\
Ebb 2 & 187350 \\
Feb 2015 (Sum): & \\
Flood 1 & 247490 \\
Ebb 1 & 356440 \\
Flood 2 & 236910 \\
Ebb 2 & 316850 \\
\hline
\end{tabular}

